\title{
Effects of Temperature, Relative Humidity, and Carbon Dioxide Concentration on Growth and Glucosinolate Content of Kale Grown in a Plant Factory
}

\author{
Milon Chowdhury ${ }^{1,2}\left(\right.$, Shafik Kiraga ${ }^{2}$, Md Nafiul Islam ${ }^{1,2} \oplus$, Mohammod Ali ${ }^{1}\left(\mathbb{D}\right.$, Md Nasim Reza ${ }^{1,2}$, \\ Wang-Hee Lee ${ }^{1,2}$ and Sun-Ok Chung ${ }^{1,2, * \mathbb{D}}$
}

1 Department of Agricultural Machinery Engineering, Graduate School, Chungnam National University, Daejeon 34134, Korea; chowdhurym90@cnu.ac.kr (M.C.); nafiulislam@cnu.ac.kr (M.N.I.); sdali77@o.cnu.ac.kr (M.A.); reza5575@cnu.ac.kr (M.N.R.); wanghee@cnu.ac.kr (W.-H.L.)

2 Department of Smart Agricultural Systems, Graduate School, Chungnam National University, Daejeon 34134, Korea; kiragashafik@o.cnu.ac.kr

* Correspondence: sochung@cnu.ac.kr; Tel.: +82-42-821-6712

\section{check for} updates

Citation: Chowdhury, M.; Kiraga, S.; Islam, M.N.; Ali, M.; Reza, M.N.; Lee, W.-H.; Chung, S.-O. Effects of Temperature, Relative Humidity, and Carbon Dioxide Concentration on Growth and Glucosinolate Content of Kale Grown in a Plant Factory. Foods 2021, 10, 1524. https://doi.org/ 10.3390 /foods10071524

Academic Editors: Franziska S. Hanschen and Sascha Rohn

Received: 16 May 2021

Accepted: 29 June 2021

Published: 1 July 2021

Publisher's Note: MDPI stays neutral with regard to jurisdictional claims in published maps and institutional affiliations.

Copyright: (c) 2021 by the authors. Licensee MDPI, Basel, Switzerland. This article is an open access article distributed under the terms and conditions of the Creative Commons Attribution (CC BY) license (https:// creativecommons.org/licenses/by/ $4.0 /)$.

\begin{abstract}
The growth of plants and their glucosinolate content largely depend on the cultivation environment; however, there are limited reports on the optimization of ambient environmental factors for kale grown in plant factories. This study was conducted to investigate the effects of temperature, relative humidity, and the carbon dioxide $\left(\mathrm{CO}_{2}\right)$ concentration on kale growth and glucosinolate content in different growth stages of cultivation in a plant factory. Kale was grown under different temperatures $\left(14,17,20,23\right.$, and $\left.26{ }^{\circ} \mathrm{C}\right)$, relative humidities $(45,55,65,75$, and $85 \%$ ), and $\mathrm{CO}_{2}$ concentrations $(400,700,1000,1300$, and $1600 \mathrm{ppm})$ in a plant factory. Two and four weeks after transplantation, leaf samples were collected to evaluate the physical growth and glucosinolate contents. The statistical significance of the treatment effects was determined by twoway analysis of variance, and Duncan's multiple range test was used to compare the means. A correlation matrix was constructed to show possible linear trends among the dependent variables. The observed optimal temperature, relative humidity, and $\mathrm{CO}_{2}$ range for growth $\left(20-23{ }^{\circ} \mathrm{C}, 85 \%\right.$, and $700-1000 \mathrm{ppm})$ and total glucosinolate content $\left(14-17^{\circ} \mathrm{C}, 55-75 \%\right.$, and $\left.1300-1600 \mathrm{ppm}\right)$ were different. Furthermore, the glucosinolate content in kale decreased with the increase of temperature and relative humidity levels, and increased with the increase of $\mathrm{CO}_{2}$ concentration. Most of the physical growth variables showed strong positive correlations with each other but negative correlations with glucosinolate components. The findings of this study could be used by growers to maintain optimum environmental conditions for the better growth and production of glucosinolate-rich kale leaves in protected cultivation facilities.
\end{abstract}

Keywords: Brassica; plant growth; glucosinolates; protected horticulture; environmental conditions

\section{Introduction}

Kale (Brassica oleracea var. alboglabra Bailey) is a salad species that is one of the most versatile and commercially valuable vegetables due to its short growth period, various uses, and desirable metabolic and nutritional profiles [1-3]. This crisp and hearty vegetable is often consumed raw in salads and smoothies but can also be consumed in steamed, sautéed, or cooked states. Kale originates from China and has since gained particular attention in other countries due to its constituent cancer-preventive and human-healthpromoting phytochemicals (i.e., glucosinolates, carotenoids, phenols, and vitamins) [4-6]. Glucosinolates are amino-acid-derived, active secondary metabolites that mainly contain sulfur- and nitrogen-related compounds (i.e., $\beta$-D-thioglucose, tryptophan, phenylalanine, sulfonated oxime moiety). They can be classified into aliphatic, aromatic, and indole groups [7], where each group consists of several chemical constituents. Progoitrin, sinigrin, 
glucoraphanin, and gluconapin are the major constituents of the aliphatic group. Similarly, 4-hydroxyglucobrassicin, glucobrassicin, 4-methoxyglucobrassicin and neoglucobrassicin, and gluconasturtiin are the major indole and aromatic glucosinolate constituents, respectively [1]. Glucosinolates are composed of relatively few amino acids and chain-elongated homologs through an independent metabolic pathway (Figure 1) and are available in all parts of almost all varieties of plants of the Brassicales order; however, the content is higher in the reproductive tissues (i.e., flowers and seeds) than in vegetative tissues [8]. The breakdown products of glucosinolates have a significant amount of anticarcinogenic activity for decreasing the risk of developing lung, stomach, colon, and rectum cancers; helping to maintain low blood pressure and reducing the risk of developing type 2 diabetes $[6,9,10]$.

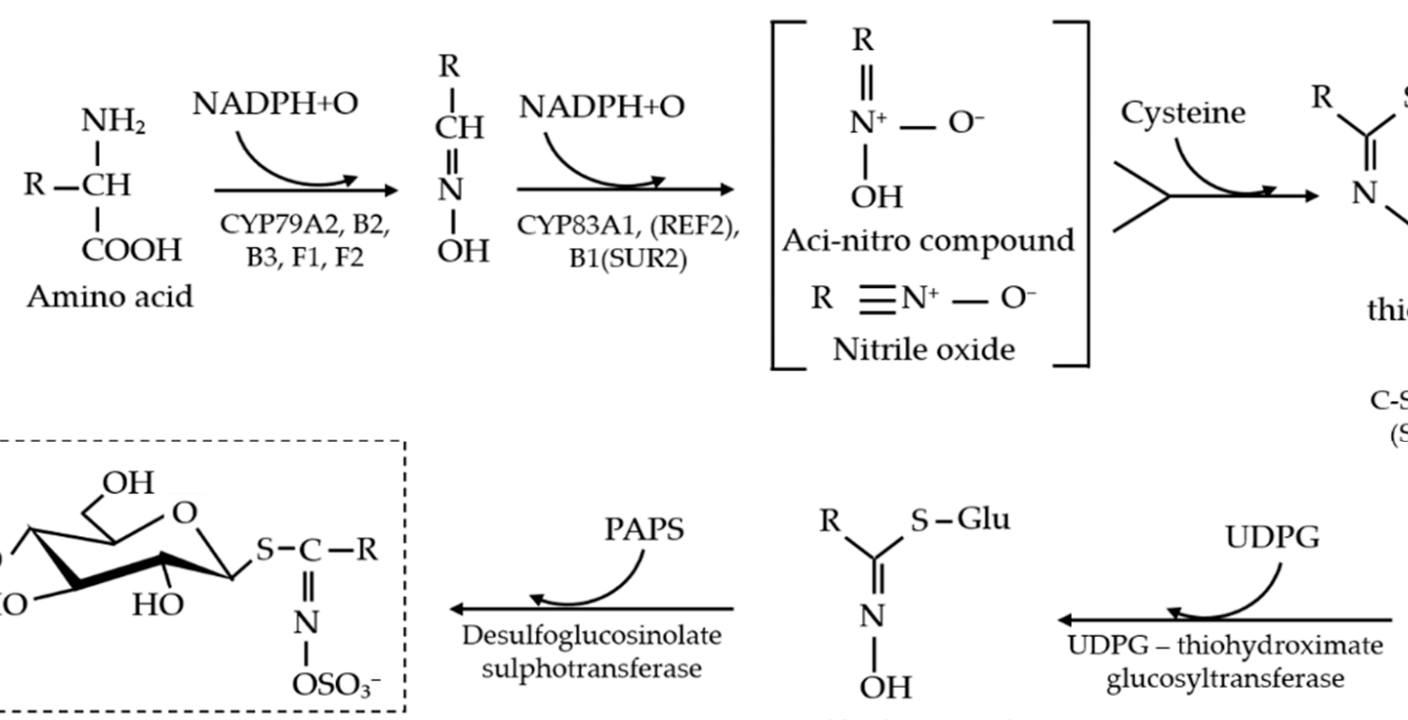

Glucosinolate

Desulfoglucosinolate
gPG - thiohydroxima
glucosyltransferase

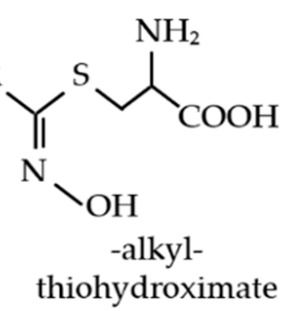

C-S lyase
(SUR)<smiles>[R]/C(S)=N/O</smiles>

Thiohydroximic acid

UDPG: uridine diphosphate glucose, PAPS: $3^{\prime}$-phosphadenosine $5^{\prime}$-phosphosulphate

NASPH: nicotinamide adenine dinucleotide phosphate

Figure 1. Synthesis of glucosinolates in Brassicaceous plants [11].

Kale growth and the formation of glucosinolates depend on crop genetic factors, tissue type, crop health, agronomic factors (i.e., water supply and fertigation), cultivation facilities (i.e., plant factory, greenhouse, and open field), and environmental factors such as temperature, relative humidity, carbon dioxide $\left(\mathrm{CO}_{2}\right)$, light type, intensity, photoperiod, and cultivation methods [12-14]. The physical development stage is also a major determinant of the glucosinolates composition in kale [15]. Although kale can be easily cultivated in open fields using traditional methods, the quality and quantity of the growth and glucosinolate content cannot be ensured, as they are extremely sensitive to climatic and field conditions [16]. In recent years, farmers have produced kale in protected cultivation facilities, such as plant factories and greenhouses, due to the possibility of adjusting the growth environment and achieving fast and sustainable growth rates, functional component-rich and high-quality yield, lower rates of disease and pest infestation, and lower labor costs in addition to the possibility of year-round production with minimum influence from geological and climatic conditions [17-19]. Moreover, hydroponic cultivation systems with ion-specific (ISE-sensor-based) nutrient management could enhance the growth and nutritional profile of kale by $15 \%$ to $60 \%$ [20-25]. However, major environmental factors (i.e., temperature, relative humidity, and $\mathrm{CO}_{2}$ ) have to be specifically optimized according to crop to ensure sustainable kale growth and glucosinolate formation.

The physical growth of kale can be easily determined by measuring its physical properties such as plant length, width, weight, number of leaves, and stem diameter, whereas the glucosinolate content needs to be identified by laboratory analysis. The deposition of 
glucosinolates in growing plants and their distribution to plant organs are significantly affected by environmental factors [26], with temperature being one of the key factors. Several studies have been conducted to determine the process and effects of temperature on seed germination, physical development, flower formation, and yield [27-30]. However, physiological processes and their integration are sped up under higher temperatures with both positive and negative effects. For example, high temperatures promote faster growth and greater fruit production of plants, especially in cereal crops, but they also remove functional components from leaves through high transpiration rates [31]. Generally, elevated temperatures affect the structural components of chloroplasts significantly, causing effects such as variation in thylakoids, granum stacking, and swelling with photosystem II reduction, resulting in disruption to the cellular cytoplasm, cell breakdown and, ultimately, cell death. In addition, rising temperatures interrupt protein mechanisms, RNA synthesis, enzymatic interactions, and cell function. As a result, these imbalances and abnormal cell functioning affect the growth and accumulation of glucosinolate synthesis $[32,33]$.

The relative humidity of the ambient environment also directly affects plant growth by resisting water and nutrient consumption. During transpiration, the relative humidity level becomes saturated. As a result, plants halt transpiration and nutrient uptake from the soil or growing media at high relative humidity levels where there is a lack of air circulation, resulting in gradual rotting in cases of long-term humidity saturation [34-36]. The maintenance of optimum relative humidity is essential for better growth and glucosinolate accumulation. Several researchers have reported that the photosynthesis rate is proportional to the relative humidity level as a higher range of relative humidity lowers water stress in the leaves and increases stomatal conductance. Although higher relative humidity increases the nutrient concentration, the nutrient solution supply and plant transpiration rate need to be monitored carefully [34,37].

The $\mathrm{CO}_{2}$ concentration influences the photosynthetic rate, metabolism, and physiological and chemical defense of plants $[13,38]$. A lack of $\mathrm{CO}_{2}$ would not only result in a lower biomass but the plants would also be of inferior quality and strength. As an essential substrate of the photosynthesis process, $\mathrm{CO}_{2}$ is directly absorbed by plants. $\mathrm{CO}_{2}$ also influences the transpiration process of plants. A meta-analysis was conducted, and it was reported that elevated $\mathrm{CO}_{2}$ could reduce transpiration by up to $22 \%$ in different plant species [39]. $\mathrm{CO}_{2}$ also preserves the essential nutrient components along with water by reducing the transpiration rate [40,41]. La et al. [38] investigated the effects of $\mathrm{CO}_{2}$ elevation at different nitrogen levels on the growth and glucosinolate content of Chinese kale and reported that all physical growth variables significantly increased with the elevation of $\mathrm{CO}_{2}$ at each nitrogen level; however, total glucosinolate content was only increased under low nitrogen level and elevated $\mathrm{CO}_{2}$ concentration.

The temperature, relative humidity, and $\mathrm{CO}_{2}$ concentration are the basic environmental factors that affect kale growth and, especially, glucosinolate formation. As they are interrelated, these factors should not be studied in isolation. The proper combination of these factors needs to be specifically confirmed for each crop to ensure optimal growth, a favorable nutritional profile, and identification of the ideal harvesting time. To date, very few studies have investigated the effects of these environmental factors on kale, especially when grown in plant factories using hydroponic cultivation methods. Therefore, the objective of this study was to investigate the effects of temperature, relative humidity, and $\mathrm{CO}_{2}$ on the growth and glucosinolate content at different stages of kale growth based on cultivation in a plant factory.

\section{Materials and Methods}

\subsection{Plant Factory and Seedling Preparation}

Plant factories are fully-closed crop cultivation systems that are fitted with artificial lights and used to grow high-value vegetables and medicinal plants throughout the year by utilizing artificially controlled ambient environmental factors $[17,19]$. In this study, five small chambers were prepared, as shown in Figure 2, to implement five different 
treatment conditions with varied temperature, relative humidity, and $\mathrm{CO}_{2}$ concentrations. The targeted environmental factors (i.e., temperature, relative humidity, and $\mathrm{CO}_{2}$ ) and other environmental factors (i.e., light sources, light intensity, photoperiod, and nutrient solution (EC and $\mathrm{pH})$ ) were maintained according to the experimental plan (Table 1). A wireless sensor network (XBee-Pro, Digi, Hopkins, MN, USA) was used to monitor the ambient environmental parameters and control the relevant actuators, as detailed by Chung et al. [42]. Three plant beds were placed vertically in each cultivation chamber, and a nutrient solution tank was kept at the bottom (floor). Each plant bed had 24 planting positions and 6 mist spray nozzles for spraying the nutrient solution onto plant roots as a fine mist for a duration of $2 \mathrm{~min}$ at 13-min intervals. Commercial nutrient solutions $\mathrm{A}$ and B (Daeyu Co., Ltd., Seoul, Korea) were used, and the target nutrient level was monitored and managed once a day using $\mathrm{EC}$ and $\mathrm{pH}$ sensors.

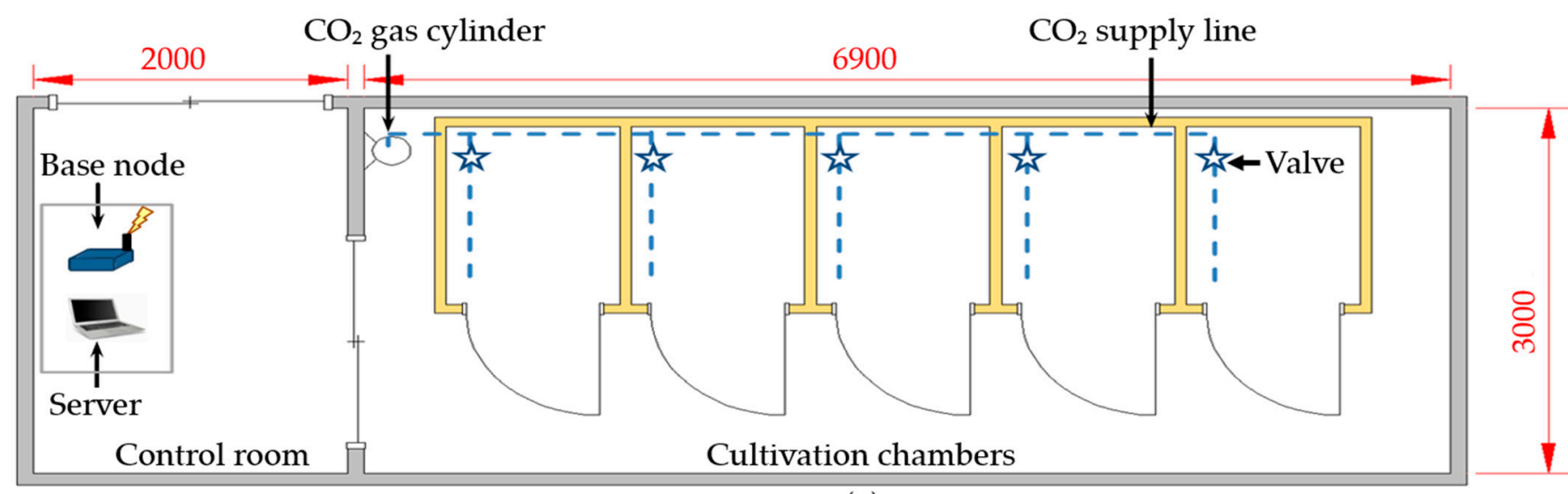

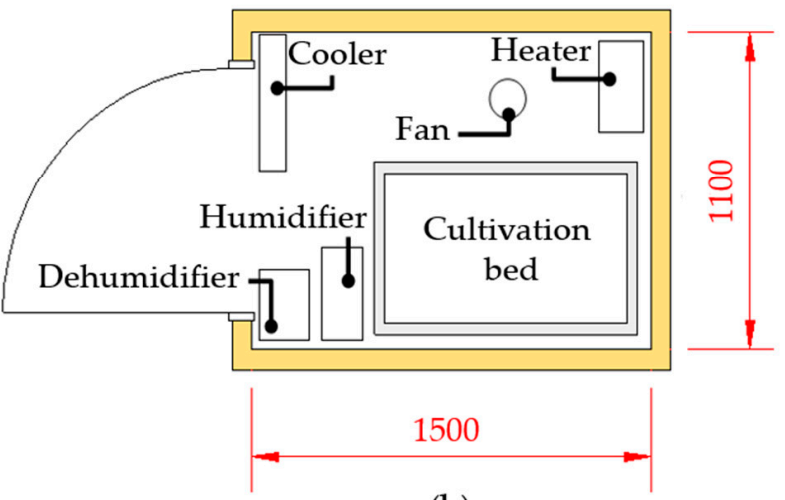

(b)

(a)

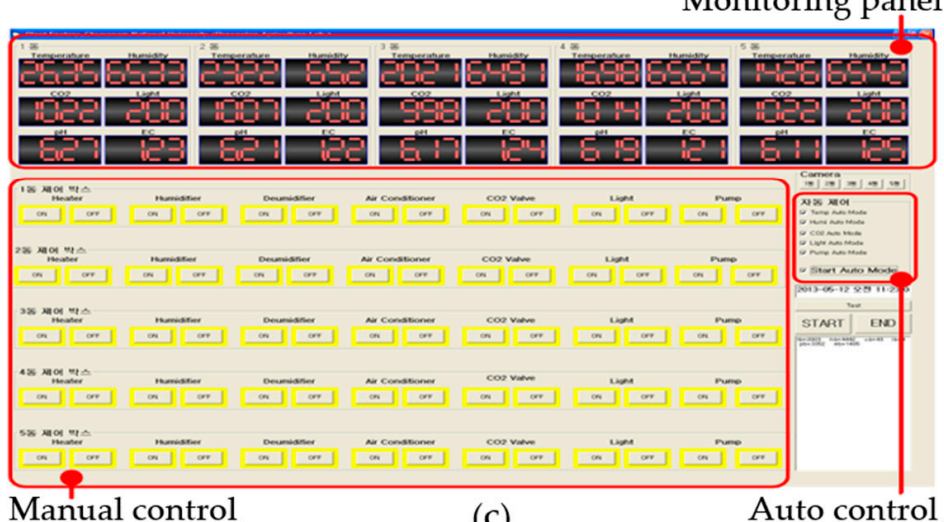

(c) Auto control

Figure 2. (a) Layout of the plant factory (control room and cultivation chambers); (b) fabricated individual chamber; and (c) ambient environment monitoring and control system. All dimensions are presented in millimeters ( $\mathrm{mm}$ ).

A commercial kale variety with green smooth leaves and a hard and fibered stem was cultivated in the experiments using a recycle-type aeroponic nutrient management system. Kale seeds were sown in a hydroponic germination sponge, covered with wet paper (until germination), kept in the plant factory under a controlled environment for germination, and grown until transplantation (Figure 3). The maintained temperature, relative humidity, $\mathrm{CO}_{2}$ concentration, light type, and photoperiod were $25 \pm 3{ }^{\circ} \mathrm{C}, 65 \pm 5 \%, 1000 \pm 100 \mathrm{ppm}$, fluorescent, and 16/8 (day/night hours), respectively. Nutrient-rich water was provided into the root zone, and the EC and $\mathrm{pH}$ of the nutrient solution were $1.2 \pm 1.00\left(\mathrm{dS} \mathrm{m}^{-1}\right)$ and $6.5 \pm 0.5$, respectively. After three weeks of germination, healthy seedlings with true leaves were transplanted into the plant bed with the sponge. 
Table 1. Different treatments of temperature, relative humidity, and $\mathrm{CO}_{2}$ during the kale cultivation in the plant factory.

\begin{tabular}{|c|c|c|c|c|c|}
\hline \multirow{2}{*}{$\begin{array}{l}\text { Environmental } \\
\text { Variables }\end{array}$} & \multicolumn{3}{|c|}{ Targeted Levels } & \multirow{2}{*}{$\begin{array}{l}\text { Monitored } \\
\text { Levels }\end{array}$} & \multirow[b]{2}{*}{ Used Sensor } \\
\hline & $\begin{array}{l}\text { Experiment } 1 \\
\text { (Temp.) }\end{array}$ & $\begin{array}{l}\text { Experiment } 2 \\
\text { (Humi.) }\end{array}$ & $\begin{array}{l}\text { Experiment } 3 \\
\left(\mathrm{CO}_{2}\right)\end{array}$ & & \\
\hline Temperature $\left({ }^{\circ} \mathrm{C}\right)$ & $\begin{array}{l}14 \pm 1 \\
17 \pm 1 \\
20 \pm 1 \\
23 \pm 1 \\
26 \pm 1\end{array}$ & $20 \pm 1$ & $20 \pm 1$ & $\begin{array}{l}14.58 \pm 0.74 \\
17.34 \pm 1.80 \\
20.25 \pm 0.69 \\
23.26 \pm 0.52 \\
25.97 \pm 1.64 \\
\end{array}$ & $\begin{array}{l}\text { ETH-01DV, ECONARAE, } \\
\text { Seoul, Korea }\end{array}$ \\
\hline $\begin{array}{c}\text { Relative } \\
\text { humidity (\%) }\end{array}$ & $65 \pm 5$ & $\begin{array}{l}45 \pm 5 \\
55 \pm 5 \\
65 \pm 5 \\
75 \pm 5 \\
85 \pm 5\end{array}$ & $65 \pm 5$ & $\begin{array}{l}44.78 \pm 5.23 \\
56.06 \pm 4.35 \\
67.66 \pm 4.67 \\
76.85 \pm 4.49 \\
82.66 \pm 5.65 \\
\end{array}$ & $\begin{array}{l}\text { ETH-01DV, ECONARAE, } \\
\text { Seoul, Korea }\end{array}$ \\
\hline $\mathrm{CO}_{2}(\mathrm{ppm})$ & $1000 \pm 100$ & $1000 \pm 100$ & $\begin{array}{c}400 \pm 100 \\
700 \pm 100 \\
1000 \pm 100 \\
1300 \pm 100 \\
1600 \pm 100\end{array}$ & $\begin{array}{c}475.62 \pm 106.30 \\
723.29 \pm 140.60 \\
980.75 \pm 125.36 \\
1318.34 \pm 125.11 \\
1672.30 \pm 93.21\end{array}$ & $\begin{array}{c}\text { SH-300-DS, SOHA TECH CO. } \\
\text { Ltd., Seoul, Korea }\end{array}$ \\
\hline $\begin{array}{l}\text { Light source } \\
\text { (LED color ratio) }\end{array}$ & & $\mathrm{R}: \mathrm{B}=11: 7$ & & - & - \\
\hline $\begin{array}{l}\text { Light intensity } \\
\left(\mu \mathrm{mol} \mathrm{m}{ }^{-2} \mathrm{~s}^{-1}\right)\end{array}$ & & 160 & & $160 \pm 25$ & $\begin{array}{l}\text { GY-30, ROHM Co. Ltd., } \\
\text { Kyoto, Japan }\end{array}$ \\
\hline $\begin{array}{c}\text { Photoperiod } \\
\text { (day/night hrs) }\end{array}$ & & $16 / 8$ & & - & $\begin{array}{c}\text { MaxiRex 5QT, Legrand Korea } \\
\text { Co., Ltd., Seoul, Korea }\end{array}$ \\
\hline $\mathrm{pH}$ & & $6.50 \pm 0.5$ & & $6.55 \pm 0.52$ & PH-BTA, Vernier, OR, USA \\
\hline $\mathrm{EC}\left(\mathrm{dS} \mathrm{m}^{-1}\right)$ & & $1.2 \pm 1.00$ & & $1.28 \pm 0.29$ & CON-BTA, Vernier, OR, USA \\
\hline
\end{tabular}

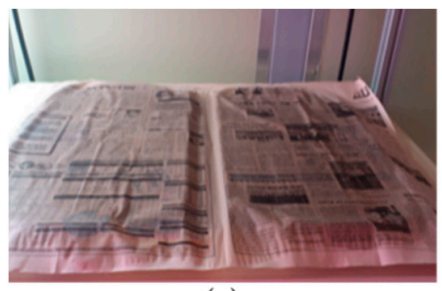

(a)

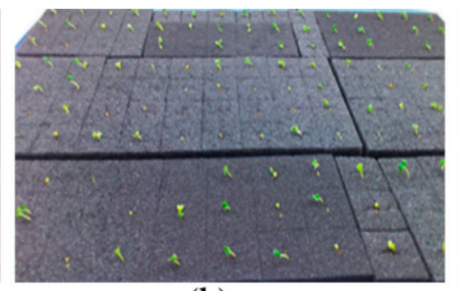

(b)

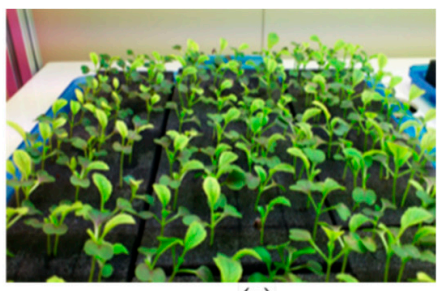

(c)

Figure 3. Preparation of kale seedlings for transplantation: (a) kale seeds were sown and covered; (b) germinated seeds; and (c) two-week-old seedlings under controlled environment conditions.

\subsection{Experimental and Analytical Procedures}

\subsubsection{Experimental Design}

Different separate experiments were conducted to investigate the influences of temperature, relative humidity, and $\mathrm{CO}_{2}$ on kale growth and glucosinolate content. Five treatments with various environmental factors were applied in each experiment. For example, temperatures of $14,17,20,23$, and $26^{\circ} \mathrm{C}$ were varied while other factors were kept constant. Similarly, five relative humidity levels and $\mathrm{CO}_{2}$ concentrations were implemented in experiments 2 and 3 to evaluate the effects of relative humidity and $\mathrm{CO}_{2}$, respectively. The targeted and monitored levels of temperature, relative humidity, and $\mathrm{CO}_{2}$ along with other growth factors are summarized in Table 1. The light source and ratio, intensity, photoperiod, and $\mathrm{pH}$ and $\mathrm{EC}$ levels were selected following the findings of Zhang et al. [43], Lefsrud et al. [44], Naznin et al. [45], and Jones [24], respectively. 


\subsubsection{Sample Collection and Data Acquisition}

Two and four weeks after transplantation (Figure 4), sample collection was performed in two steps. First, mature and healthy plants were visually selected and collected from the plant beds for physical growth evaluation. Three plants from each bed and nine plants from three beds (replicates) of each cultivation chamber were collected randomly among 72 plants ( 24 plants/bed $\times 3$ plant beds). To analyze the glucosinolate content, three normal-sized, mature, healthy leaves were harvested from each plant bed (one leaf from each collected plant), and a total of nine leaves were collected from three plant beds (as a replication) from each cultivation chamber. The measured values for each growth parameter and the glucosinolate content were averaged to represent one data point. As a result, nine data points for growth parameters and one data point for the glucosinolate content were recorded from each plant bed. In total, 270 data points were collected for growth evaluation ( 9 data points/bed $\times 2$ sampling times $\times 3$ replications $\times 5$ treatments) and 30 data points were collected to assess the glucosinolate content $(1$ data point/bed $\times 2$ sampling times $\times 3$ replications $\times 5$ treatments) for each experiment. The physical growth variables, namely, the plant height, width, weight, number of leaves, stem diameter, chlorophyll level, leaf length, width, and weight were measured, and the leaves were transferred to the chemical laboratory immediately (to minimize the degradation) for glucosinolate analysis using a commercial high-performance liquid chromatography (HPLC) machine (model: 1200 series, Agilent Technologies, Santa Clara, CA, USA). The chlorophyll concentration was also measured using a commercial device (model: SPAD 502DL, Spectrum Technology Inc., Aurora, IL, USA).

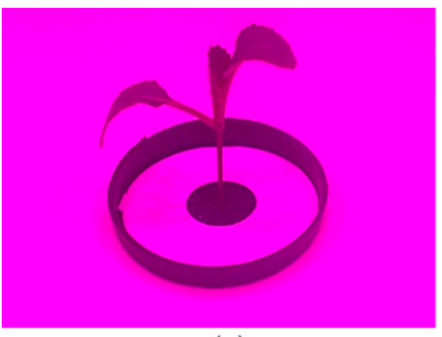

(a)

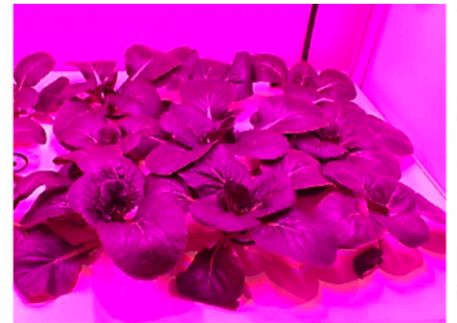

(b)

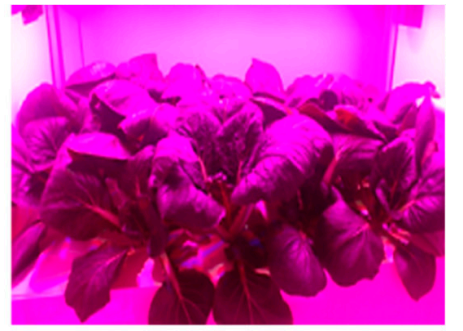

(c)

Figure 4. Growth condition of kale after different periods of transplantation: (a) transplantation day; (b) 2 weeks after transplantation; and (c) 4 weeks after transplantation.

\subsubsection{Estimation of Glucosinolate Content}

The glucosinolates of the freshly harvested kale leaves were extracted and analyzed as described by Doheny-Adams et al. [46]. The whole process was conducted according to the ISO 9167:2019 [47], and the process is divided into four major steps: (a) tissue disruption, (b) extraction in methanol, (c) purification and desulfation, and (d) separation and identification of glucosinolates by HPLC analysis (1200 series, Agilent Technologies, Santa Clara, CA, USA). The collected leaf samples were stored in an airtight box, taken to the chemical laboratory immediately to freeze in liquid nitrogen, and stored at $-80^{\circ} \mathrm{C}$ for $48 \mathrm{~h}$ to reduce the activity of myrosinase. For freeze-drying, samples were lightly wrapped with aluminum foil and transported on dry ice to load into the freeze drier (Lyotrap, LTE scientific Ltd., Oldham, UK) within $30 \mathrm{~s}$. The freeze-dried leaf samples were ground to make a homogenized fine powder using a grinder (EK2311, Salter, Tonbridge, UK). Then, $100 \mathrm{mg}$ of the freeze-dried samples was preheated for $3 \mathrm{~min}$ at $75^{\circ} \mathrm{C}$ and $4.5 \mathrm{~mL}$ of preheated $70 \%$ methanol at $75^{\circ} \mathrm{C}$ was added. The sample was incubated for $10 \mathrm{~min}$ at $75^{\circ} \mathrm{C}$ (with manual shaking every $2 \mathrm{~min}$ ) and then centrifuged by a rotor at $4000 \mathrm{rpm}$ (B 3.11, Jouan, Nantes, France) for $10 \mathrm{~min}$. In the purification step, $25 \mathrm{mg}$ of sulfatase and $1 \mathrm{ml}$ of $40 \%$ ethanol were mixed and centrifuged for $1 \mathrm{~min}$ at $8000 \mathrm{rpm}$. The supernatant was shifted to a new Eppendorf tube and $1 \mathrm{~mL}$ of pure ethanol was injected for precipitating the sulfatase before the second centrifugation. Finally, the sulfatase pellet was air dried after separating 
from the supernatant and diluted in $2 \mathrm{~mL}$ of water. For desulfation, $0.5 \mathrm{cc}$ of Sephadex slurry was used to prepare the columns and $2 \mathrm{~mL}$ of imizadole formate $(6 \mathrm{M})$ was added on each for activation. The columns were cleaned twice with $1 \mathrm{~mL}$ of water each time. The columns were washed again using $1 \mathrm{~mL}$ of $20 \mathrm{mM}$ sodium acetate, and $75 \mu \mathrm{L}$ of purified sulfatase $(0.05-0.3 \mathrm{U} / \mathrm{mL})$ was injected. After that, columns were incubated for $24 \mathrm{~h}$ at $28^{\circ} \mathrm{C}$ before desulfoglucosinolates were eluted with two $1 \mathrm{~mL}$ volumes of water. After $24 \mathrm{~h}$ of incubation, elution of desulfoglucosinolates was performed thrice using $1.5 \mathrm{~mL}$ of distilled water and filtered through $0.45-\mu \mathrm{m}$ polytetrafluoroethylene (PTFE) syringe filters (Millipore, Bedford, MA, USA) into an HPLC vial. A reverse phase C18 column $(150 \times 3.0 \mathrm{~mm}, 3 \mu \mathrm{m}$, Inertsil ODS-3, GL Sciences, Tokyo, Japan) was used, which was equilibrated for $30 \mathrm{~min}$ using ultrapure water (solvent A) and 100\% acetonitrile (solvent B) with detection at $227 \mathrm{~nm}$. The flow rate was $0.4 \mathrm{~mL} \mathrm{~min}^{-1}$, and separation was performed according to the default program. As an external standard, sinigrin $(0.1 \mathrm{mg} / \mathrm{mL}$; Sigma, St. Louis, MO, USA) was utilized. The identification and quantification of individual glucosinolate components was performed by comparing the sinigrin retention time and using their HPLC areas and response factor, respectively. In this study, the obtained retention time for progoitrin, sinigrin, glucobrassicin, 4-methoxyglucobrassicin, and neoglucobrassicin were $5.97,7.13,21.93,24.68$, and $30.37 \mathrm{~min}$, respectively.

\subsubsection{Statistical Analysis}

All the presented physical growth parameters and glucosinolate content values are the means of independent measurements for different treatments of each environmental factor. The significance of differences between mean values was determined by two-way analysis of variance (ANOVA). Data were analyzed considering $95 \%$ confidence levels and two-sided confidence intervals. Duncan's multiple range test was used to simultaneously compare means (SAS Institute Inc, Campus drive Cary, NC, USA). A correlation matrix recording correlation coefficients was created to show the inter-relationships between variables.

\section{Results}

\subsection{ANOVA of the Environmental Factors}

The effects of ambient environmental factors (temperature, relative humidity, and $\mathrm{CO}_{2}$ ) on plant physical growth variables and total glucosinolate content were analyzed using two-way ANOVA analysis. Five different treatment conditions for each environmental factor and two sampling times were considered when conducting the ANOVA analysis for each growth variable and the glucosinolate content. The results of the two-way ANOVA analysis for the plant height, width, weight, and total glucosinolate content are shown in Table 2 out of nine physical variables and five identified glucosinolate components. The F-values of the treatments and sampling times were higher than the F crit values, except for some growth and glucosinolate variables under the $\mathrm{CO}_{2}$ treatments, which confirms the adequacy of the hypothesis. This ANOVA analysis indicates that the treatments and sampling times had significant impacts $(p<0.05)$ on the growth and glucosinolate content (except for some $\mathrm{CO}_{2}$ treatments). However, some P-values under the $\mathrm{CO}_{2}$ treatments were higher than 0.05 , which also indicates that those growth or glucosinolate variables were not notably affected by the $\mathrm{CO}_{2}$ treatments. The overall results show that a single unit change of each environmental factor will affect the plant growth and glucosinolate content. 
Table 2. Two-way ANOVA test showing the individual effects of the treatments (Tr) and sampling times (ST) on growth variables and total glucosinolate content of kale.

\begin{tabular}{|c|c|c|c|c|c|c|c|c|c|c|c|c|}
\hline \multirow{2}{*}{ SV } & \multicolumn{3}{|c|}{ Plant Height } & \multicolumn{3}{|c|}{ Plant Width } & \multicolumn{3}{|c|}{ Plant Weight } & \multicolumn{3}{|c|}{ Total Glucosinolates } \\
\hline & $\operatorname{Tr}$ & ST & Err & $\operatorname{Tr}$ & ST & Err & $\operatorname{Tr}$ & ST & Err & $\operatorname{Tr}$ & ST & Err \\
\hline \multicolumn{13}{|c|}{ Temperature effect } \\
\hline ss & $4.1 \times 10^{4}$ & $2.3 \times 10^{5}$ & $6.6 \times 10^{3}$ & $1.4 \times 10^{4}$ & $4.3 \times 10^{4}$ & $3.2 \times 10^{3}$ & 206.9 & $1.03 \times 10^{3}$ & 298.2 & $8.7 \times 10^{3}$ & $3.7 \times 10^{3}$ & $3.2 \times 10^{3}$ \\
\hline df & 4 & 1 & 20 & 4 & 1 & 20 & 4 & 1 & 20 & 4 & 1 & 20 \\
\hline MS & $1.0 \times 10^{4}$ & $2.3 \times 10^{5}$ & 334.1 & $3.5 \times 10^{3}$ & $4.3 \times 10^{4}$ & 162.1 & 51.71 & $1.3 \times 10^{3}$ & 14.91 & $2.1 \times 10^{3}$ & $3.7 \times 10^{3}$ & 162.6 \\
\hline F-value & 30.89 & 714.63 & & 21.71 & 269.3 & & 3.46 & 69.01 & & 13.45 & 22.99 & \\
\hline$p$-value & $<0.001$ & $<0.001$ & & $<0.001$ & $<0.001$ & & $<0.05$ & $<0.001$ & & $<0.001$ & $<0.001$ & \\
\hline F crit & 2.87 & 4.35 & & 2.87 & 4.35 & & 2.87 & 4.35 & & 2.87 & 4.35 & \\
\hline \multicolumn{13}{|c|}{ Relative humidity effect } \\
\hline ss & $5.1 \times 10^{3}$ & $2.03 \times 10^{4}$ & 4708 & $1.8 \times 10^{4}$ & $1.1 \times 10^{5}$ & $1.3 \times 10^{4}$ & 6.53 & 192.53 & 7.33 & 0.34 & 1.16 & 1.93 \\
\hline df & 4 & 1 & 20 & 4 & 1 & 4 & 4 & 1 & 20 & 4 & 1 & 20 \\
\hline MS & $1.3 \times 10^{3}$ & $2.03 \times 10^{4}$ & 235.4 & 4607.4 & $1.1 \times 10^{5}$ & 632.4 & 1.63 & 192.53 & 0.37 & 0.08 & 1.16 & 0.09 \\
\hline F-value & 5.49 & 86.37 & & 7.29 & 189.27 & & 4.45 & 525.09 & & 0.88 & 12.01 & \\
\hline$p$-value & $<0.05$ & $<0.001$ & & $<0.001$ & $<0.001$ & & $<0.05$ & $<0.001$ & & 0.49 & $<0.05$ & \\
\hline F crit & 2.867 & 4.35 & & 2.87 & 4.35 & & 2.87 & 4.35 & & 2.87 & 0.41 & \\
\hline \multicolumn{13}{|c|}{$\mathrm{CO}_{2}$ effect } \\
\hline ss & 652.8 & 3020 & 1187.3 & 311.67 & $4.4 \times 10^{4}$ & $1.4 \times 10^{4}$ & 0.252 & 898.7 & 4.08 & 64.46 & 3.18 & 55.65 \\
\hline df & 4 & 1 & 20 & 4 & 1 & 20 & 4 & 1 & 20 & 4 & 1 & 20 \\
\hline MS & 163.2 & 3020 & 59.37 & 77.91 & $4.4 \times 10^{4}$ & 748.5 & 0.06 & 898.7 & 0.204 & 16.11 & 3.18 & 2.78 \\
\hline F-value & 2.75 & 50.8 & & 0.10 & 59.31 & & 0.31 & 4398.3 & & 5.79 & 1.14 & \\
\hline$p$-value & 0.05 & $<0.001$ & & 0.97 & $<0.001$ & & 0.86 & $<0.001$ & & $<0.05$ & 0.29 & \\
\hline F crit & 2.87 & 4.35 & & 2.87 & 4.35 & & 2.87 & 4.35 & & 2.87 & 4.35 & \\
\hline
\end{tabular}

SV: source of variation, SS: sum of square, df: degree of freedom, MS: mean square, F crit: critical value in the F distribution, Tr: treatment, ST: sampling times, Err: error, E: exponential.

\subsection{Correlation of the Glucosinolates Components}

Table 3 shows the magnitude, direction, and linear pairwise relationship between the identified glucosinolate variables under the considered ambient environmental factors (temperature, relative humidity, and $\mathrm{CO}_{2}$ ). Among the five identified glucosinolate variables under the temperature experiments, sinigrin and glucobrassicin were strongly and positively correlated among them and identified glucosinolate variables under the relative humidity experiments, and they were strongly and negatively correlated with the variables identified in the $\mathrm{CO}_{2}$ experiments. The correlations were statistically significant at a $0.1 \%$ level (except for some variables). Although, progoitrin had a significant positive correlation with each of the five identified glucosinolate variables under the $\mathrm{CO}_{2}$ experiments, no significant correlations were observed with other variables. Except for some strong correlations, 4-methoxyglucobrassicin, and neoglucobrassicin were also not significantly correlated with other identified glucosinolate variables. Strong negative correlations with a $0.1 \%$ significance level were observed for most of the identified glucosinolate variables under the relative humidity and $\mathrm{CO}_{2}$ experiments. However, identified glucosinolate variables under the $\mathrm{CO}_{2}$ experiments were strongly and positively correlated. They were statistically significant at a $0.1 \%$ level (except for the C_Sin). The multicollinearity issue can also be predicted from the correlation matrix. A highly correlated value $(>0.7)$ hinders the evaluation of the true effects of the predictor variables. According to Table 3, some of the glucosinolate variables had notable evidence of strong correlation. For example, C_Pro showed positive correlations of 0.90, 0.90, and 0.99 with C_Glu, C_4-met, and C_Neo, respectively, and C_4-met showed negative correlations of -0.91 and -0.93 , with T_Sin and T_Glu, respectively. Variance inflation factor (VIF) was also investigated and the values varied from 1 to 3 for most of the variables, indicating that the variables were slightly explained by other independent variables. However, the VIF values of T_Sin (4.72) and T_Glu (6.46) were relatively high [48].

\subsection{Evaluation of Temperature Effects}

A statistical analysis was conducted to evaluate the effects of temperature on kale growth, and the results are shown in Table 4 . Regarding kale physical properties, an overall high growth rate was observed at $20-23^{\circ} \mathrm{C}$, and the lowest growth rate occurred at $14^{\circ} \mathrm{C}$. However, some physical parameters showed greater numbers at 17 and $26^{\circ} \mathrm{C}$. They were plant height $\left(17^{\circ} \mathrm{C}\right)$ and width $\left(26^{\circ} \mathrm{C}\right)$ after two weeks of transplantation, and chlorophyll level $\left(17^{\circ} \mathrm{C}\right)$, leaf length and weight $\left(26^{\circ} \mathrm{C}\right)$ after four weeks of transplantation. The data points of no. of leaves, stem diameter, and leaf parameters (length, width, and 
weight) were very close to the mean (low standard deviation); however, the data points of other growth variables, especially plant height and width, were spread out over a wide range of values. Standard deviation was greater in samples collected after four weeks of cultivation, compared to the two weeks. According to Duncan's range test results, significant differences were observed for the plant width, weight, and leaf parameters (length, width, and weight) at 2-week sampling time, and the plant height, and leaf parameters at 4-week sampling time, depending on the temperature levels. Contrariwise, the rest of the growth variables (specifically the number of leaves, stem diameter, and chlorophyll level) did not show statistical significance regarding the temperature variations.

Table 3. Correlation matrix of the identified glucosinolate components under the temperature, humidity, and $\mathrm{CO}_{2}$ treatments.

\begin{tabular}{|c|c|c|c|c|c|c|c|c|c|c|c|c|c|c|c|}
\hline Variables & T_Pro & T_Sin & T_Glu & $\begin{array}{l}\text { T_4- } \\
\text { met }\end{array}$ & T_Neo & H_Pro & H_Sin & H_Glu & $\begin{array}{l}\text { H_4- } \\
\text { met }\end{array}$ & H_Neo & C_Pro & C_Sin & C_Glu & $\begin{array}{l}\text { C_4- } \\
\text { met }\end{array}$ & C_Neo \\
\hline T_Pro & 1.00 & & & & & & & & & & & & & & \\
\hline T_Sin & -0.02 & 1.00 & & & & & & -1 & -0.6 & -0.2 & 0 & 0.2 & 0.6 & +1 & \\
\hline T_Glu & -0.12 & $\begin{array}{c}0.96 \\
* * *\end{array}$ & 1.00 & & & & & & & & & & & & \\
\hline $\begin{array}{l}\text { T_4- } \\
\text { met }\end{array}$ & -0.13 & -0.65 & $\begin{array}{c}-0.59 \\
* * *\end{array}$ & 1.00 & & & & \multirow{2}{*}{\multicolumn{2}{|c|}{$\begin{array}{c}\text { Strong } \\
\text { negative }\end{array}$}} & Not corr & elated & & \multirow{2}{*}{\multicolumn{2}{|c|}{$\begin{array}{c}\text { Strong } \\
\text { positive }\end{array}$}} & \\
\hline T_Neo & $0.51^{* * *}$ & $\begin{array}{c}0.74 \\
* * *\end{array}$ & $\begin{array}{c}0.76 \\
* * *\end{array}$ & $\begin{array}{c}-0.52 \\
* * *\end{array}$ & 1.00 & & & & & & & & & & \\
\hline H_Pro & $\underset{* * *}{-0.52}$ & 0.24 & $\begin{array}{l}0.50 \\
* * *\end{array}$ & -0.08 & 0.25 & 1.00 & & & & & & & & & \\
\hline H_Sin & -0.13 & 0.08 & -0.06 & $-\underset{* * *}{-0.66}$ & -0.26 & $\begin{array}{c}-0.35 \\
*\end{array}$ & 1.00 & & & & & & & & \\
\hline H_Glu & -0.01 & $\underbrace{0.53}_{* * *}$ & $\begin{array}{c}0.66 \\
* * *\end{array}$ & 0.14 & $\underset{* * *}{0.65}$ & $\begin{array}{c}0.59 \\
* * *\end{array}$ & $\begin{array}{c}-0.79 \\
* * *\end{array}$ & 1.00 & & & & & & & \\
\hline $\begin{array}{l}\text { H_4- } \\
\text { met }\end{array}$ & -0.21 & -0.54 & $\begin{array}{c}-0.36 \\
*\end{array}$ & $\underset{* * *}{0.88}$ & -0.29 & 0.37 * & -0.82 & $\underset{* *}{0.41}$ & 1.00 & & & & & & \\
\hline H_Neo & 0.00 & $\underbrace{0.52}_{* * *}$ & $0.35^{*}$ & 0.11 & 0.16 & $\begin{array}{c}-0.38 \\
*\end{array}$ & -0.13 & $0.30^{*}$ & -0.17 & 1.00 & & & & & \\
\hline C_Pro & $\underset{* * *}{0.70}$ & $\underset{* * *}{-0.64}$ & $\begin{array}{c}-0.69 \\
* * *\end{array}$ & 0.06 & -0.11 & $\underset{* * *}{-0.50}$ & 0.13 & $\underset{* * *}{-0.54}$ & -0.03 & $\underset{* * *}{-0.53}$ & 1.00 & & & & \\
\hline C_Sin & $0.37^{*}$ & $\begin{array}{c}0.68 \\
* * *\end{array}$ & $\underset{* * *}{0.71}$ & $\begin{array}{c}-0.84 \\
* * *\end{array}$ & $\underset{* * *}{0.86}$ & $0.31 *$ & 0.17 & $0.30 *$ & $\underset{* * *}{-0.56}$ & -0.17 & -0.01 & 1.00 & & & \\
\hline C_Glu & $\begin{array}{l}0.70 \\
* * *\end{array}$ & $-0.63^{* *}$ & $\underset{* * *}{-0.58}$ & 0.27 & 0.04 & -0.22 & -0.28 & -0.16 & $0.31 *$ & $\begin{array}{c}-0.57 \\
* * *\end{array}$ & 0.90 & 0.01 & 1.00 & & \\
\hline $\begin{array}{l}\text { C_4- } \\
\text { met }\end{array}$ & $0.36^{*}$ & $\underset{* * *}{-0.91}$ & $\begin{array}{c}-0.93 \\
* * *\end{array}$ & $0.36^{*}$ & $\underset{* * *}{-0.52}$ & $-\underset{* *}{-0.45}$ & 0.11 & $\underset{* * *}{-0.66}$ & 0.22 & $\begin{array}{c}-0.57 \\
* * *\end{array}$ & $\begin{array}{l}0.90 \\
* * *\end{array}$ & $\begin{array}{l}-0.40 \\
* *\end{array}$ & 0.80 & 1.00 & \\
\hline C_Neo & $\begin{array}{l}0.77 \\
* * *\end{array}$ & $\underset{* * *}{-0.50}$ & $\underset{* * *}{-0.56}$ & -0.08 & 0.03 & $\begin{array}{l}-0.47 \\
* *\end{array}$ & 0.17 & $\begin{array}{c}-0.49 \\
* *\end{array}$ & -0.14 & $\underset{* * *}{-0.53}$ & $\begin{array}{l}0.99 \\
* * *\end{array}$ & 0.16 & $\underset{* * *}{0.88}$ & $\begin{array}{l}0.81 \\
* * *\end{array}$ & 1.00 \\
\hline VIF & 1.06 & 4.72 & 6.46 & 2.83 & 1.57 & 1.32 & 1.09 & 1.14 & 1.47 & 1.01 & 1.56 & 2.39 & 1.63 & 2.92 & 1.28 \\
\hline
\end{tabular}

$*, * *, * * *$ indicate the $5 \%, 1 \%$, and $0.1 \%$ significance levels, respectively. T_Pro, T_Sin, T_Glu, T_4-met, T_Neo: progoitrin, sinigrin, glucobrassicin, 4-methoxyglucobrassicin, and neoglucobrassicin observed under experiment 1 (temperature effect); H_Pro, H_Sin, H_Glu, H_4-met, H_Neo: progoitrin, sinigrin, glucobrassicin, 4-methoxyglucobrassicin, and neoglucobrassicin observed under experiment 2 (relative humidity effect); C_Pro, C_Sin, C_Glu, C_4-met, C_Neo: progoitrin, sinigrin, glucobrassicin, 4-methoxyglucobrassicin, and neoglucobrassicin observed under experiment $3\left(\mathrm{CO}_{2}\right.$ effect $)$, respectively. VIF: variance inflation factor.

Table 4. Effects of different temperature levels on kale growth at different cultivation periods.

\begin{tabular}{|c|c|c|c|c|c|c|c|c|c|c|}
\hline \multirow[b]{2}{*}{ Sampling Time } & \multirow{2}{*}{$\begin{array}{l}\text { Temp. } \\
\text { Level } \\
\left({ }^{\circ} \mathrm{C}\right)\end{array}$} & \multicolumn{9}{|c|}{ Growth Variables } \\
\hline & & $\underset{(\mathrm{mm})}{P_{-} \text {Height }}$ & $\underset{(\mathrm{mm})}{P_{-} \text {Width }}$ & $\begin{array}{c}\text { P_Weight } \\
\text { (g) }\end{array}$ & No_Leaf & $\begin{array}{c}\text { Stem dia. } \\
(\mathrm{mm})\end{array}$ & $\begin{array}{c}\text { Chlor_Level } \\
\text { (ppm) }\end{array}$ & $\begin{array}{c}\text { L_Length } \\
\text { (mm) }\end{array}$ & $\underset{(\mathrm{mm})}{\mathrm{L}_{\text {_Width }}}$ & $\underset{\text { (g) }}{L_{-} \text {Weight }}$ \\
\hline \multirow{5}{*}{ 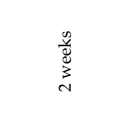 } & 14 & $95.0 \pm 4.5 \mathrm{a}$ & $161.7 \pm 8.1 \mathrm{~b}$ & $11.9 \pm 1.2 \mathrm{~b}$ & $7.0 \pm 0.0^{\mathrm{a}}$ & $2.4 \pm 0.1^{\mathrm{a}}$ & $46.9 \pm 1.0^{\mathrm{a}}$ & $8.4 \pm 0.5^{c}$ & $7.4 \pm 0.4^{c}$ & $2.9 \pm 0.2 \mathrm{~b}$ \\
\hline & 17 & $99.3 \pm 4.7^{\mathrm{a}}$ & $186.0 \pm 24.3 \mathrm{ab}$ & $12.6 \pm 0.3 \mathrm{a}$ & $6.7 \pm 3.7 \mathrm{a}$ & $2.5 \pm 0.2^{\mathrm{a}}$ & $49.1 \pm 0.6^{\mathrm{a}}$ & $10.6 \pm 0.2 \mathrm{~b}$ & $9.4 \pm 0.4^{b}$ & $5.2 \pm 0.6^{\mathrm{a}}$ \\
\hline & 20 & $84.7 \pm 1.2^{\mathrm{a}}$ & $167.0 \pm 22.7 \mathrm{~b}$ & $13.3 \pm 0.2^{\mathrm{a}}$ & $7.0 \pm 0.1 \mathrm{a}$ & $2.7 \pm 0.1 \mathrm{a}$ & $53.4 \pm 5.4^{\mathrm{a}}$ & $13.0 \pm 0.4^{\mathrm{a}}$ & $11.3 \pm 0.6^{\mathrm{a}}$ & $6.3 \pm 0.4^{\mathrm{a}}$ \\
\hline & 23 & $92.3 \pm 11^{\mathrm{a}}$ & $196.0 \pm 14.2^{\mathrm{ab}}$ & $13.0 \pm 0.3 \mathrm{a}$ & $7.0 \pm 0.1^{\mathrm{a}}$ & $2.8 \pm 0.9^{\mathrm{a}}$ & $57.0 \pm 2.8 \mathrm{a}$ & $12.8 \pm 0.8$ a & $11.1 \pm 0.6^{a b}$ & $6.0 \pm 1.1^{a}$ \\
\hline & 26 & $90.3 \pm 8.9^{a}$ & $215.0 \pm 14.1^{\mathrm{a}}$ & $13.3 \pm 0.3^{\mathrm{a}}$ & $7.0 \pm 0.8^{\mathrm{a}}$ & $2.8 \pm 0.2^{\mathrm{a}}$ & $52.0 \pm 0.3^{\mathrm{a}}$ & $12.6 \pm 0.9^{\mathrm{a}}$ & $11.3 \pm 0.4^{\mathrm{a}}$ & $5.8 \pm 0.2^{\mathrm{a}}$ \\
\hline \multirow{5}{*}{ 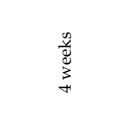 } & 14 & $115.3 \pm 8.3^{\mathrm{b}}$ & $274.3 \pm 15.0^{\mathrm{a}}$ & $21.3 \pm 4.1^{\mathrm{a}}$ & $11.1 \pm 0.2^{\mathrm{a}}$ & $13.0 \pm 0.0^{\mathrm{a}}$ & $55.5 \pm 4.3^{\mathrm{a}}$ & $19.9 \pm 0.8^{c}$ & $12.6 \pm 0.46^{\mathrm{b}}$ & $9.2 \pm 0.9^{b}$ \\
\hline & 17 & $129.7 \pm 5.3^{\mathrm{b}}$ & $260.3 \pm 39.4^{\mathrm{a}}$ & $23.6 \pm 6.2^{\mathrm{a}}$ & $12.7 \pm 0.5^{\mathrm{a}}$ & $14.3 \pm 0.5^{\mathrm{a}}$ & $61.2 \pm 2.4^{\mathrm{a}}$ & $26.7 \pm 0.2^{b}$ & $17.1 \pm 1.1 \mathrm{ab}$ & $16.0 \pm 3.3 \mathrm{ab}$ \\
\hline & 20 & $143.3 \pm 6.5 \mathrm{ab}$ & $286.3 \pm 13.5^{\mathrm{a}}$ & $28.3 \pm 4.3 \mathrm{a}$ & $12.0 \pm 0.7 \mathrm{a}$ & $15.7 \pm 0.4^{\mathrm{a}}$ & $48.4 \pm 15.1^{\mathrm{a}}$ & $31.2 \pm 2.0^{a b}$ & $19.0 \pm 1.4^{\mathrm{a}}$ & $19.1 \pm 6.1 \mathrm{a}$ \\
\hline & 23 & $137.3 \pm 8.6 \mathrm{ab}$ & $278.3 \pm 36.5^{\mathrm{a}}$ & $25.4 \pm 3.2^{\mathrm{a}}$ & $13.5 \pm 1.3^{\mathrm{a}}$ & $17.7 \pm 0.4^{\mathrm{a}}$ & $58.5 \pm 1.7^{\mathrm{a}}$ & $31.8 \pm 2.5^{\mathrm{ab}}$ & $20.2 \pm 1.8^{\mathrm{a}}$ & $20.0 \pm 3.8^{\mathrm{a}}$ \\
\hline & 26 & $176.3 \pm 27.7^{a}$ & $277.0 \pm 12.8^{\mathrm{a}}$ & $22.2 \pm 4.8^{\mathrm{a}}$ & $10.0 \pm 0.4^{\mathrm{a}}$ & $15.6 \pm 0.9^{\mathrm{a}}$ & $53.6 \pm 4.3^{\mathrm{a}}$ & $37.0 \pm 2.5 \mathrm{a}$ & $19.8 \pm 1.5^{\mathrm{a}}$ & $20.1 \pm 5.7^{\mathrm{a}}$ \\
\hline
\end{tabular}

a, b, c Different letters in the same column indicate a significant difference $(p \leq 0.05)$. P_height: plant height, $P_{-}$width: plant width, $P_{-} w e i g h t:$ plant weight, No_leaf: number of leaves, Stem dia.: stem diameter, Chlor_level: chlorophyll level, L_length: leaf length, L_width: leaf width, L_weight: leaf weight. 
Figure 5 shows the effects of temperature on the glucosinolate content, based on various components, of harvested kale leaves after two and four weeks of transplantation. Glucobrassicin was found to be a dominant glucosinolate component in both cases. However, an inverse relationship was observed between the contents of all glucosinolate components and increased ambient temperature levels and cultivation period. The total glucosinolate content became lower at each increased temperature level, and the lowest total glucosinolate of kale leaves in each sampling time was observed at $26^{\circ} \mathrm{C}$. A high standard deviation trend was observed for each glucosinolate component due to the low sampling number. Among the five levels of temperature, the total glucosinolate content was higher at $14-17^{\circ} \mathrm{C}$ in both cultivation periods. According to Duncan's range test, the concentrations of sinigrin, glucobrassicin, and 4-methoxyglucobrassicin were significantly different for each temperature level in samples collected after two weeks of cultivation; however, no significant differences were observed among the other glucosinolate components (except sinigrin at 4th week) for different temperature levels and cultivation periods.

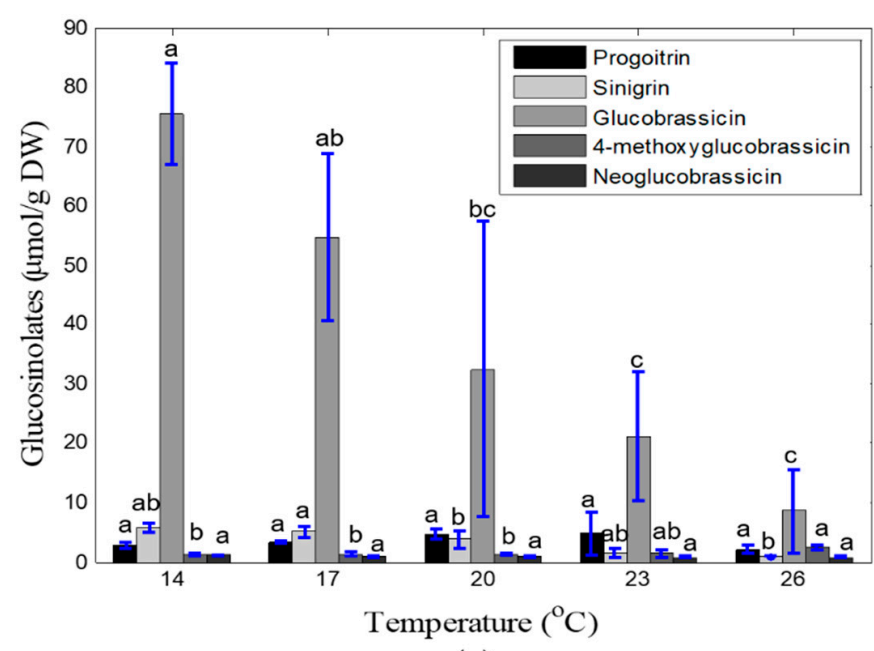

(a)

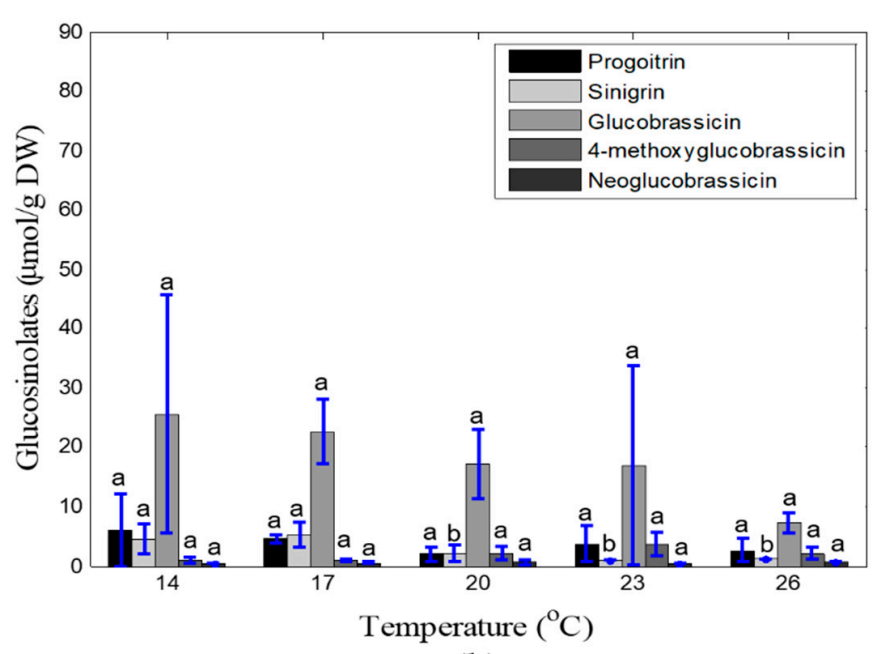

(b)

Figure 5. Concentrations of glucosinolate components ( $\mu \mathrm{mol} / \mathrm{g} \mathrm{DW})$ under different temperature treatments and cultivation periods: two weeks after transplantation (a) and four weeks after transplantation (b). ${ }^{a}, b, c$ levels of components with the same letters are not significantly different at $p<0.05$.

The interactions of each growth variable and glucosinolate component under the different temperature treatments after four weeks of transplantation were analyzed using the correlation matrix and the results are summarized in Table 5, where the level of significance and VIF are also mentioned. In many cases, strong positive and negative correlation coefficients were observed. The physical growth variables were found to be strongly correlated with each other (around 0.50-0.98). However, the chlorophyll level showed negative correlations with all the growth variables, and positive correlations were observed with progoitrin, sinigrin, and glucobrassicin. The progoitrin, sinigrin, and glucobrassicin were strongly positively correlated with each other and negatively correlated with 4-methoxyglucobrassicin and neoglucobrassicin. Moreover, the detected glucosinolate components (except 4-methoxyglucobrassicin) were negatively correlated with most of the physical growth variables. According to the VIF analysis, most of the variables were moderately correlated; however, some variables (i.e., leaf length and glucobrassicin) were highly correlated, which might adversely affect other variables.

\subsection{Evaluation of Relative Humidity Effects}

The effects of relative humidity on kale growth properties are summarized in Table 6. The growth status was evaluated at two different stages (two and four weeks after transplantation). Most of the physical growth variables were prominent at the $85 \%$ relative humidity level at both sampling periods, except for the number of leaves, stem diameter, 
chlorophyll level (55\%), and leaf length (75\%) in the second week, and the number of leaves, leaf weight $(65 \%)$, and chlorophyll level $(45 \%)$ in the fourth week of cultivation. Except for some growth variables, the overall lowest growth performance was observed at the $45 \%$ relative humidity level in both sampling times. The data points of some growth variables, such as plant height and width, leaf length and width, were spread out over a wide range compared to other growth variables, and greater standard deviations were observed in samples collected after four weeks of cultivation, compared to the two weeks of cultivation. According to Duncan's range test, all the growth variables (except the chlorophyll level) were significantly different at the 2-week sampling time depending on the relative humidity levels. A similar result was observed (except for the plant weight, chlorophyll level, and leaf width) at the 4-week sampling time.

Table 5. Correlation matrix showing kale growth and glucosinolate variables and their constituents (experiment 1).

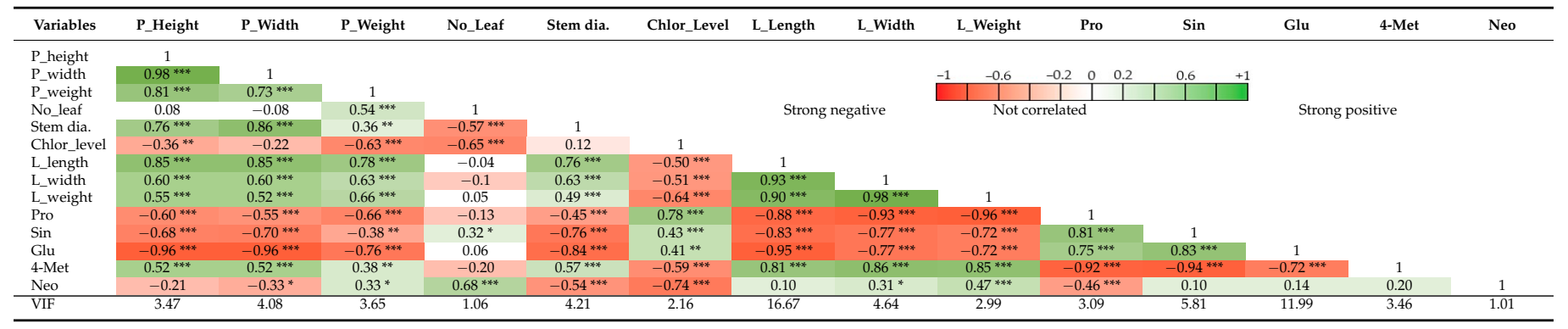

${ }^{*}, * *, * * *$ indicate the $5 \%, 1 \%$, and $0.1 \%$ significance levels, respectively. P_height: plant height, P_width: plant width, P_weight: plant weight, No_leaf: number of leaves, Stem dia.: stem diameter, Chlor_level: chlorophyll level, L_length: leaf length, L_width: leaf width, L_weight: leaf weight, Pro: progoitrin, Sin: sinigrin, Glu: glucobrassicin, 4-Met: 4-methoxyglucobrassicin, and Neo: neoglucobrassicin. VIF: variance inflation factor.

Table 6. Effects of different relative humidity levels on kale growth in different cultivation periods.

\begin{tabular}{|c|c|c|c|c|c|c|c|c|c|c|}
\hline \multirow[b]{2}{*}{ Sampling Time } & \multirow{2}{*}{$\begin{array}{l}\text { Humi. } \\
\text { Level } \\
(\%)\end{array}$} & \multicolumn{9}{|c|}{ Growth Variables } \\
\hline & & $\underset{(\mathrm{mm})}{\mathrm{P}_{-} \text {Height }}$ & $\begin{array}{c}\text { P_Width } \\
(\mathrm{mm})\end{array}$ & $\underset{\text { (g) }}{\text { P_Weight }}$ & No_Leaf & $\begin{array}{c}\text { Stem Dia. } \\
(\mathrm{mm})\end{array}$ & $\begin{array}{c}\text { Chlor_Level } \\
\text { (ppm) }\end{array}$ & $\underset{(\mathrm{mm})}{\text { L_Length }}$ & $\underset{(\mathrm{mm})}{\mathrm{L}_{-} \text {Width }}$ & $\underset{\text { (g) }}{\mathrm{L}_{-} \text {Weight }}$ \\
\hline \multirow{5}{*}{ 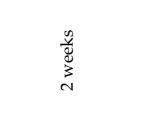 } & 45 & $68.7 \pm 7.6^{b}$ & $171.7 \pm 8.1 \mathrm{~b}$ & $5.5 \pm 0.1^{\mathrm{c}}$ & $8.0 \pm 0.0 \mathrm{ab}$ & $2.9 \pm 0.2^{c}$ & $60.5 \pm 4.3 \mathrm{a}$ & $97.7 \pm 9.5^{c}$ & $58.0 \pm 2.0^{c}$ & $1.1 \pm 0.1^{\mathrm{c}}$ \\
\hline & 55 & $74.3 \pm 10.3^{b}$ & $196.0 \pm 24.3 \mathrm{ab}$ & $8.2 \pm 1.2 \mathrm{ab}$ & $8.7 \pm 0.6^{\mathrm{a}}$ & $3.8 \pm 0.3^{\mathrm{a}}$ & $66.2 \pm 2.4^{\mathrm{a}}$ & $111.7 \pm 9.5 \mathrm{bc}$ & $67.7 \pm 5.5 \mathrm{bc}$ & $1.8 \pm 0.4^{\mathrm{b}}$ \\
\hline & 65 & $79.3 \pm 5.1 \mathrm{ab}$ & $177.0 \pm 22.6^{b}$ & $6.3 \pm 1.4 \mathrm{bc}$ & $7.7 \pm 0.6^{b}$ & $3.3 \pm 0.2^{b}$ & $53.4 \pm 15.1^{\mathrm{a}}$ & $114.0 \pm 5.6 \mathrm{~b}$ & $67.3 \pm 5.1 \mathrm{bc}$ & $1.8 \pm 0.2^{b}$ \\
\hline & 75 & $83.0 \pm 1.0^{a b}$ & $206.0 \pm 14.2 \mathrm{ab}$ & $7.7 \pm 1.2 \mathrm{abc}$ & $8.0 \pm 0.1 \mathrm{ab}$ & $3.2 \pm 0.2 \mathrm{bc}$ & $63.5 \pm 1.7^{\mathrm{a}}$ & $133.3 \pm 9.1 \mathrm{a}$ & $76.7 \pm 4.6^{\mathrm{ab}}$ & $2.1 \pm 0.3 \mathrm{ab}$ \\
\hline & 85 & $93.3 \pm 6.8^{\mathrm{a}}$ & $225.0 \pm 14.1^{a}$ & $8.9 \pm 1.5^{\mathrm{a}}$ & $8.0 \pm 0.0 \mathrm{ab}$ & $3.5 \pm 0.1 \mathrm{ab}$ & $58.6 \pm 4.3^{\mathrm{a}}$ & $132.3 \pm 8.6^{\mathrm{a}}$ & $81.7 \pm 8.4^{\mathrm{a}}$ & $2.5 \pm 0.3^{a}$ \\
\hline \multirow{5}{*}{ 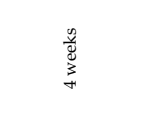 } & 45 & $114.3 \pm 9.3^{b}$ & $291.7 \pm 62.8^{\mathrm{b}}$ & $23.4 \pm 10.2^{\mathrm{a}}$ & $13.0 \pm 1.0 \mathrm{bc}$ & $5.0 \pm 0.7^{\mathrm{c}}$ & $66.1 \pm 1.6^{\mathrm{a}}$ & $158.7 \pm 25.2^{b}$ & $105.3 \pm 21.7^{\mathrm{a}}$ & $5.3 \pm 1.3^{b}$ \\
\hline & 55 & $119.7 \pm 15.3^{b}$ & $302.0 \pm 18.1 \mathrm{~b}$ & $29.4 \pm 3.5^{\mathrm{a}}$ & $13.3 \pm 0.6 \mathrm{ab}$ & $5.2 \pm 0.3 \mathrm{bc}$ & $65.3 \pm 1.8^{\mathrm{a}}$ & $171.0 \pm 14.1 \mathrm{ab}$ & $118.0 \pm 7.9 \mathrm{a}$ & $8.9 \pm 1.5^{a}$ \\
\hline & 65 & $133.3 \pm 16.5^{a b}$ & $314.0 \pm 18.0^{b}$ & $33.0 \pm 4.9 \mathrm{a}$ & $14.7 \pm 0.6 \mathrm{a}$ & $5.0 \pm 0.2^{\mathrm{c}}$ & $47.1 \pm 2.8 \mathrm{a}$ & $172.3 \pm 17.1 \mathrm{ab}$ & $111.3 \pm 9.1^{\mathrm{a}}$ & $9.1 \pm 1.1^{\mathrm{a}}$ \\
\hline & 75 & $125.3 \pm 9.6^{\mathrm{b}}$ & $316.3 \pm 7.6^{\mathrm{b}}$ & $25.7 \pm 0.9 \mathrm{a}$ & $11.7 \pm 0.6^{\mathrm{c}}$ & $5.7 \pm 0.3 \mathrm{ab}$ & $61.3 \pm 3.1^{\mathrm{a}}$ & $186.3 \pm 6.4 \mathrm{ab}$ & $114.7 \pm 9.7 \mathrm{a}$ & $8.9 \pm 2.2^{\mathrm{a}}$ \\
\hline & 85 & $166.3 \pm 37.9^{\mathrm{a}}$ & $383.3 \pm 10.1^{a}$ & $34.7 \pm 6.9 \mathrm{a}$ & $13.0 \pm 1.0 \mathrm{bc}$ & $6.1 \pm 0.1 \mathrm{a}$ & $59.2 \pm 3.1 \mathrm{a}$ & $191.0 \pm 11.5^{a}$ & $126.0 \pm 12.5 \mathrm{a}$ & $8.7 \pm 2.3^{\mathrm{a}}$ \\
\hline
\end{tabular}

a, b, c Different letters in the same column indicate significant differences $(p \leq 0.05)$. P_height: plant height, P_width: plant width, $P_{-}$weight: plant weight, No_leaf: number of leaves, Stem dia.: stem diameter, Chlor_level: chlorophyll level, L_length: leaf length, L_width: leaf width, L_weight: leaf weight.

The results of the glucosinolate analysis for different relative humidity treatments and cultivation periods are shown in Figure 6. The aliphatic glucosinolates (i.e., progoitrin, sinigrin) and indole glucosinolate (i.e., glucobrassicin) were the most prominent components at both of the sampling times. The overall glucosinolate concentrations decreased slightly in the samples collected after the fourth week of cultivation. A high standard deviation was observed, especially for the glucobrassicin, as the sample number was low and sometimes all glucosinolate components were not detected in some samples. According to Duncan's range test, no significant differences were observed among the glucosinolate components (except for the progoitrin, glucobrassicin, and 4-methoxyglucobrassicin at the 2-week sampling time) for different relative humidity treatments and cultivation periods.

Table 7 shows the correlation matrix of physical and glucosinolate properties for different relative humidity treatments after four weeks of cultivation. All physical growth variables, except for the number of leaves and the chlorophyll level, showed strong positive correlations with one another. A fairly good correlation (both positive and negative) was observed between the physical variables and glucosinolate components. However, most of the 
glucosinolate components were negatively correlated with each other. Moreover, the VIF values were also determined. Except for the leaf length (VIF: 11.93), other predictors were moderately correlated, which resulted in a low influence on other independent variables.

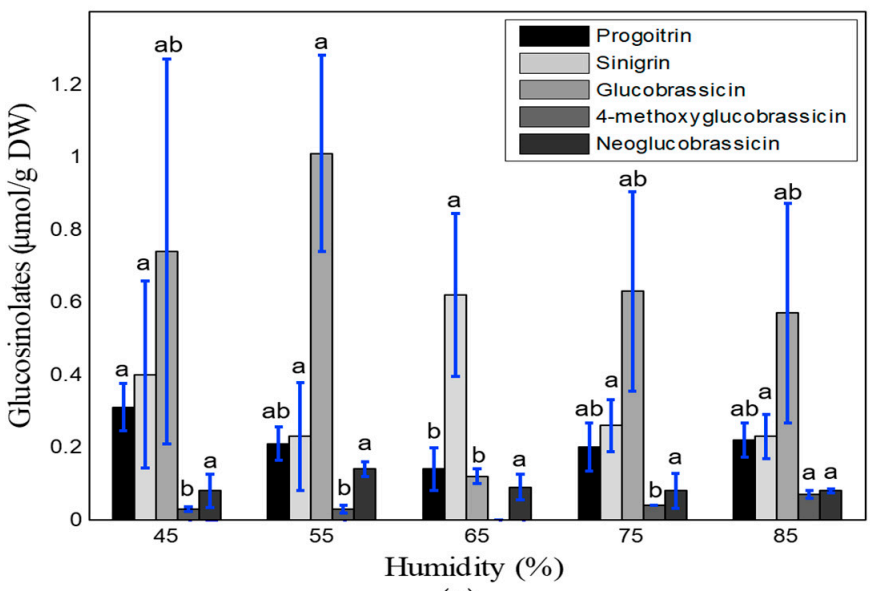

(a)

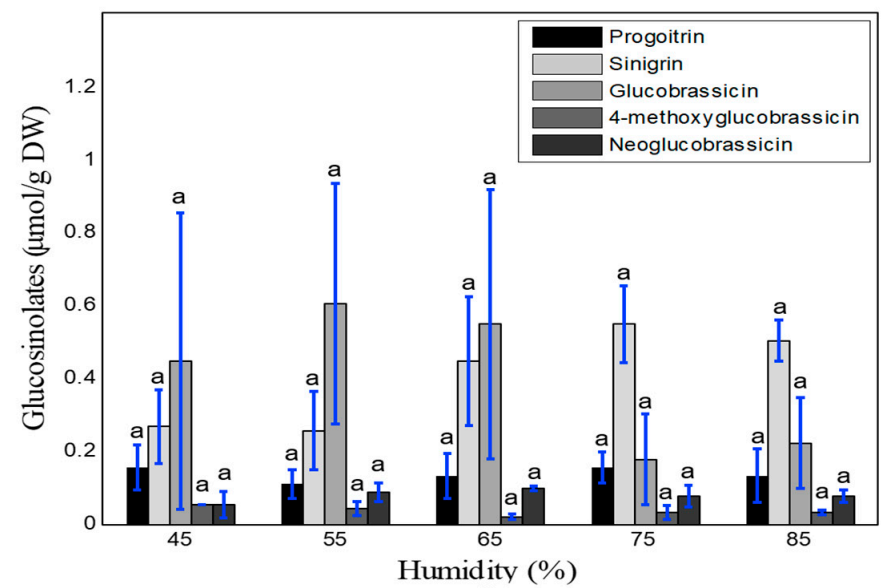

(b)

Figure 6. Concentrations of glucosinolate components $(\mu \mathrm{mol} / \mathrm{g} \mathrm{DW})$ under different relative humidity treatments and cultivation periods: two weeks after transplantation (a) and four weeks after transplantation (b). ${ }^{a}, b$ levels of components with the same letters are not significantly different at $p<0.05$.

Table 7. Correlation matrix showing kale growth and glucosinolate variables and their constituents (experiment 2).

\begin{tabular}{|c|c|c|c|c|c|c|c|c|c|c|c|c|c|c|}
\hline Variables & P_Height & P_Width & P_Weight & No_Leaf & Stem Dia. & Chlor_Level & L_Length & L_Width & L_Weight & Pro & Sin & Glu & 4-Met & Neo \\
\hline P_height & 1 & & & & & & & & & & & & & \\
\hline P_width & $0.99 * * *$ & 1 & & & & & & & -0.6 & $\begin{array}{lll}0.2 & 0 & 0.2\end{array}$ & 0.6 & & & \\
\hline P_weight & $0.81^{* * * *}$ & $0.73^{* * *}$ & 1 & & & & & & 1 & & 11 & & & \\
\hline No_leaf & 0.08 & -0.08 & $0.54 * * *$ & 1 & & & \multicolumn{2}{|c|}{ Strong negative } & Not c & lated & & \multicolumn{2}{|c|}{ Strong positive } & \\
\hline $\begin{array}{l}\text { No_em dia. } \\
\text { Stem }\end{array}$ & $0.76^{* * * *}$ & 0.86 **** & 0.36 ** & $\begin{array}{c}1 \\
-0.57 * * *\end{array}$ & 1 & & & & & & & & & \\
\hline Chlor_level & -0.36 ** & -0.22 & $-0.63 * * *$ & $-0.65^{* * *}$ & 0.12 & 1 & & & & & & & & \\
\hline L_length & 0.76 **** & $0.81 * * *$ & $0.53^{* * *}$ & $-0.39 * *$ & $0.91 * * *$ & -0.21 & 1 & & & & & & & \\
\hline L_width & $0.80 * * *$ & 0.85 *** & $0.71 * * *$ & -0.14 & $0.81 * * *$ & -0.02 & $0.82 * * *$ & 1 & & & & & & \\
\hline L_weight & $0.42 * * *$ & $0.40^{* *}$ & $0.67^{* * *}$ & 0.12 & 0.37 ** & $-0.50^{* * *}$ & $0.69 * * *$ & $0.65^{* * *}$ & 1 & & & & & \\
\hline $\begin{array}{l}\text { Pro } \\
\text { Pro }\end{array}$ & -0.17 & -0.13 & -0.60 *** & -0.50 **** & 0.09 & 0.09 & -0.04 & $-0.51^{* * *}$ & $-0.54^{* * *}$ & 1 & & & & \\
\hline $\begin{array}{l}\text { Pin } \\
\text { Sin }\end{array}$ & $0.61 * * *$ & $\begin{array}{l}-0.13 * \\
0.62 * *\end{array}$ & -0.38 ** & $\begin{array}{l}-0.50 * \\
-0.29 *\end{array}$ & $0.69 * * * *$ & $\begin{array}{l}0.09 \\
-0.5 * *\end{array}$ & 0.85 *.0** & $0.42^{* * * *}$ & $-0.55 * * * *$ & 0.34 ** & 1 & & & \\
\hline Glu & $-0.49 * * *$ & -0.59 *** & 0.04 & $0.74 * * *$ & $\begin{array}{l}0.09 \\
-0.85 * * *\end{array}$ & $\begin{array}{l}-0.50 \\
-0.13\end{array}$ & $\begin{array}{l}0.03 \\
-0.72 * * *\end{array}$ & $\begin{array}{l}0.42 \\
-0.37 \text { ** }\end{array}$ & -0.05 & $-0.60 * * *$ & -0.76 *** & 1 & & \\
\hline 4-Met & -0.39 ** & -0.35 ** & -0.47 **** & -0.03 & -0.40 ** & $0.73 *$ **** & $-0.68 * * *$ & $-0.31 *$ & $-0.79 * * *$ & -0.05 & -0.86 *** & 0.35 ** & 1 & \\
\hline Neo & 0.28 * & 0.20 & $0.70^{* * * *}$ & $0.46 * * *$ & 0.03 & $-0.68^{* * *}$ & $0.41^{* *}$ & $0.42 * * *$ & $0.93^{* * *}$ & $-0.64 * * *$ & $0.34^{* *}$ & $0.28^{*}$ & $-0.72 * * *$ & 1 \\
\hline VIF & $\frac{1.20}{3.47}$ & $\frac{4.20}{4.07}$ & $\frac{0.65}{2.65}$ & $\frac{0.40}{1.06}$ & 4.03 & $\begin{array}{l}.00 \\
1.16\end{array}$ & $\frac{1.71}{11.93}$ & $\frac{0.42}{2.56}$ & 1.78 & 1.11 & $\begin{array}{l}.07 \\
4.97\end{array}$ & 2.01 & 1.42 & $\frac{1}{1.22}$ \\
\hline
\end{tabular}

$*, * *, * * *$ indicates $5 \%, 1 \%$, and $0.1 \%$ significance levels, respectively. P_height: plant height, $P_{-}$width: plant width, $P_{-}$weight: plant weight, No_leaf: number of leaves, Stem dia.: stem diameter, Chlor_level: chlorophyll level, L_length: leaf length, L_width: leaf width, L_weight: leaf weight, Pro: progoitrin, Sin: sinigrin, Glu: glucobrassicin, 4-met: 4-methoxyglucobrassicin, and Neo: neoglucobrassicin. VIF: variance inflation factor.

\subsection{Evaluation of $\mathrm{CO}_{2}$ Effects}

A summary of the effects of $\mathrm{CO}_{2}$ treatments and cultivation periods on kale growth is given in Table 8. The overall growth performance was higher under 700-1000 ppm $\mathrm{CO}_{2}$. However, a notable growth rate of some parameters (i.e., chlorophyll level and leaf length at the 2-week sampling time, and plant height and chlorophyll level at the 4-week sampling time) was observed under $400 \mathrm{ppm}$ of $\mathrm{CO} 2$. Relatively low growth performance was observed under 1300 and $1600 \mathrm{ppm}$ of $\mathrm{CO}_{2}$ in both sampling periods. Besides this, the spread of standard deviations of the growth variables was almost similar for both of the sampling periods. Comparatively high standard deviations were observed for the plant parameters (height, width, and weight) and chlorophyll level compared to other growth variables. Based on Duncan's range test results, there were no significant differences for the growth parameters (except the plant height at the 4-week sampling time) under different $\mathrm{CO}_{2}$ concentrations and cultivation periods.

The effects of different $\mathrm{CO}_{2}$ concentrations on the glucosinolate content are shown in Figure 7. The optimal $\mathrm{CO}_{2}$ level in relation to the total glucosinolate content was $1300 \mathrm{ppm}$ at both the second and fourth weeks of cultivation. The progoitrin, sinigrin, and neoglucobrassicin contents decreased after the two weeks of cultivation. The low sampling number caused high standard deviations of the detected glucosinolate components. Glucobrassicin 
was found to be a dominant component in the samples collected after 4-weeks. The results of Duncan's range test showed a significant difference in glucosinolate components (except for the 4-methoxyglucobrassicin and neoglucobrassicin at the 2-week sampling, and sinigrin, glucobrassicin, and neoglucobrassicin at the 4-week sampling time) under different $\mathrm{CO}_{2}$ concentrations and both cultivation periods.

Table 8. Effects of different carbon dioxide levels on kale growth at different cultivation periods.

\begin{tabular}{|c|c|c|c|c|c|c|c|c|c|c|}
\hline \multirow[b]{2}{*}{ Sampling Time } & \multirow{2}{*}{$\begin{array}{c}\mathrm{CO}_{2} \\
\text { Level (ppm) }\end{array}$} & \multicolumn{9}{|c|}{ Growth Variables } \\
\hline & & $\underset{(\mathrm{mm})}{\text { P_Height }}$ & $\begin{array}{c}\text { P_Width } \\
(\mathrm{mm})\end{array}$ & $\underset{\text { (g) }}{\text { P_Weight }}$ & No_Leaf & $\begin{array}{c}\text { Stem Dia. } \\
(\mathrm{mm})\end{array}$ & $\begin{array}{c}\text { Chlor_Level } \\
\text { (ppm) }\end{array}$ & $\begin{array}{c}\text { L_Length } \\
\text { (mm) }\end{array}$ & $\underset{(\mathrm{mm})}{\mathrm{L}_{\text {_Width }}}$ & $\underset{\text { (g) }}{\text { L_Weigh }}$ \\
\hline \multirow{5}{*}{ 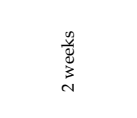 } & 400 & $85.0 \pm 4.5 \mathrm{a}$ & $213.0 \pm 9.2^{a}$ & $11.0 \pm 1.8^{\mathrm{a}}$ & $4.2 \pm 0.3 \mathrm{a}$ & $11.3 \pm 0.4^{\mathrm{a}}$ & $142.0 \pm 10.0^{\mathrm{a}}$ & $53.0 \pm 4.2^{\mathrm{a}}$ & $60.1 \pm 1.4^{a}$ & $3.5 \pm 0.2^{\circ}$ \\
\hline & 700 & $89.3 \pm 4.7$ a & $228.0 \pm 11.7 \mathrm{a}$ & $11.3 \pm 1.7 \mathrm{a}$ & $4.2 \pm 0.2 \mathrm{a}$ & $11.7 \pm 0.44^{a}$ & $140.7 \pm 5.4^{\mathrm{a}}$ & $47.7 \pm 1.2^{\mathrm{a}}$ & $63.0 \pm 4.3^{\mathrm{a}}$ & $3.6 \pm 1.1^{a}$ \\
\hline & 1000 & $74.7 \pm 1.2 \mathrm{a}$ & $196.3 \pm 16.8^{a}$ & $10.4 \pm 1.4^{\mathrm{a}}$ & $4.3 \pm 0.3 \mathrm{a}$ & $11.7 \pm 0.4 \mathrm{a}$ & $127.0 \pm 6.1^{\mathrm{a}}$ & $50.0 \pm 4.0^{\mathrm{a}}$ & $64.1 \pm 3.2^{\mathrm{a}}$ & $3.4 \pm 0.4$ \\
\hline & 1300 & $82.3 \pm 11.0^{\mathrm{a}}$ & $211.3 \pm 4.5^{\mathrm{a}}$ & $8.9 \pm 0.4^{\mathrm{a}}$ & $4.0 \pm 0.1 \mathrm{a}$ & $11.0 \pm 0.8$ a & $125.0 \pm 1.4 \mathrm{a}$ & $45.3 \pm 4.1 \mathrm{a}$ & $69.8 \pm 1.1 \mathrm{a}$ & $\begin{array}{l}.4 \pm 0.4^{\circ} \\
3.2 \pm 0.6^{\circ}\end{array}$ \\
\hline & 1600 & $80.3 \pm 8.9^{\mathrm{a}}$ & $194.0 \pm 17.2^{\mathrm{a}}$ & $7.5 \pm 0.6^{\mathrm{a}}$ & $4.0 \pm 0.3^{\mathrm{a}}$ & $11.7 \pm 0.9^{\mathrm{a}}$ & $123.0 \pm 7.2^{\mathrm{a}}$ & $52.3 \pm 3.2^{\mathrm{a}}$ & $66.8 \pm 1.3^{\mathrm{a}}$ & $2.9 \pm 0.2^{a}$ \\
\hline \multirow{5}{*}{\begin{tabular}{l}
$\frac{g}{8}$ \\
\multirow{3}{*}{} \\
$\forall$
\end{tabular}} & 400 & $111.7 \pm 6.5^{\mathrm{a}}$ & $284.3 \pm 13.0^{\mathrm{a}}$ & $22.2 \pm 4.8^{\mathrm{a}}$ & $7.0 \pm 0.4 \mathrm{a}$ & $14.7 \pm 0.9^{\mathrm{a}}$ & $186.0 \pm 14.3 \mathrm{a}$ & $68.0 \pm 2.1^{\mathrm{a}}$ & $62.7 \pm 2.8^{a}$ & $5.7 \pm 1.7^{\circ}$ \\
\hline & 700 & $105.3 \pm 4.7 \mathrm{ab}$ & $270.3 \pm 49.4^{a}$ & $28.4 \pm 3.2^{a}$ & $7.1 \pm 0.3^{a}$ & $15.7 \pm 0.4^{\mathrm{a}}$ & $179.0 \pm 9.9^{a}$ & $67.3 \pm 4.7^{a}$ & $66.9 \pm 1.3^{a}$ & $5.3 \pm 0.8^{\mathrm{a}}$ \\
\hline & 1000 & $102.7 \pm 4.9 \mathrm{ab}$ & $296.3 \pm 6.5^{\mathrm{a}}$ & $25.0 \pm 4.3^{\mathrm{a}}$ & $7.4 \pm 0.4 \mathrm{a}$ & $15.7 \pm 0.4^{\mathrm{a}}$ & $175.7 \pm 5.2^{\mathrm{a}}$ & $70.3 \pm 2.4^{a}$ & $65.6 \pm 0.8^{a}$ & $4.5 \pm 0.1^{\mathrm{a}}$ \\
\hline & 1300 & $99.3 \pm 5.5 \mathrm{ab}$ & $288.3 \pm 36.5^{a}$ & $23.6 \pm 6.2^{\mathrm{a}}$ & $6.7 \pm 0.5 \mathrm{a}$ & $14.3 \pm 0.5^{a}$ & $169.3 \pm 12.0^{\mathrm{a}}$ & $63.0 \pm 2.0^{a}$ & $67.7 \pm 1.2^{\mathrm{a}}$ & $4.7 \pm 1.3^{\mathrm{a}}$ \\
\hline & 1600 & $93.0 \pm 5.0^{b}$ & $288.0 \pm 12.8^{\mathrm{a}}$ & $25.3 \pm 4.1^{\mathrm{a}}$ & $7.1 \pm 0.2 \mathrm{a}$ & $15.0 \pm 0.0^{\mathrm{a}}$ & $179.0 \pm 11.3 \mathrm{a}$ & $68.3 \pm 4.1^{\mathrm{a}}$ & $66.4 \pm 2.4^{\mathrm{a}}$ & $4.9 \pm 0.9^{\mathrm{a}}$ \\
\hline
\end{tabular}

$\mathrm{a}, \mathrm{b}$ Different letters in the same column indicate significant differences $(p \leq 0.05)$. P_height: plant height, $P_{-}$width: plant width, $P_{-}$weight: plant weight, No_leaf: number of leaves, Stem dia.: stem diameter, Chlor_level: chlorophyll level, L_length: leaf length, L_width: leaf width, L_weight: leaf weight.

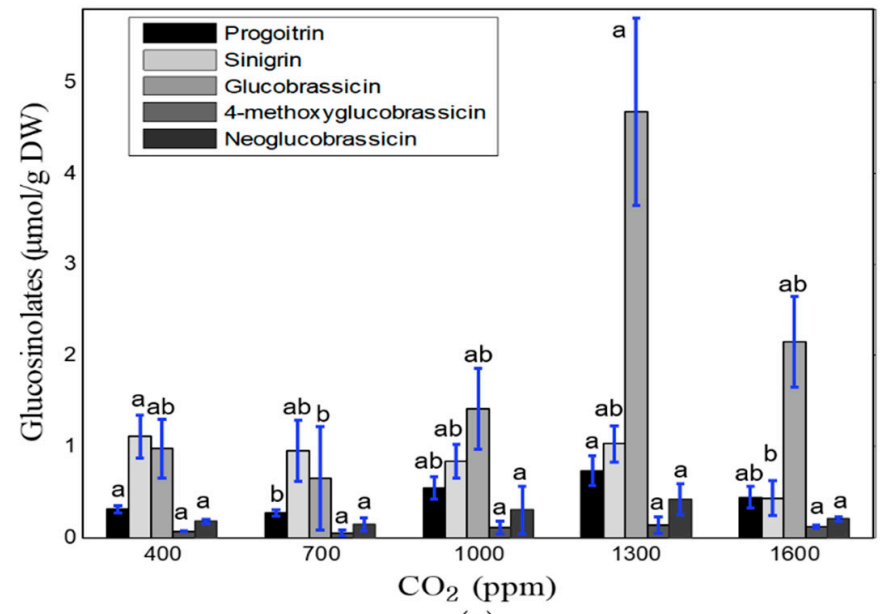

(a)

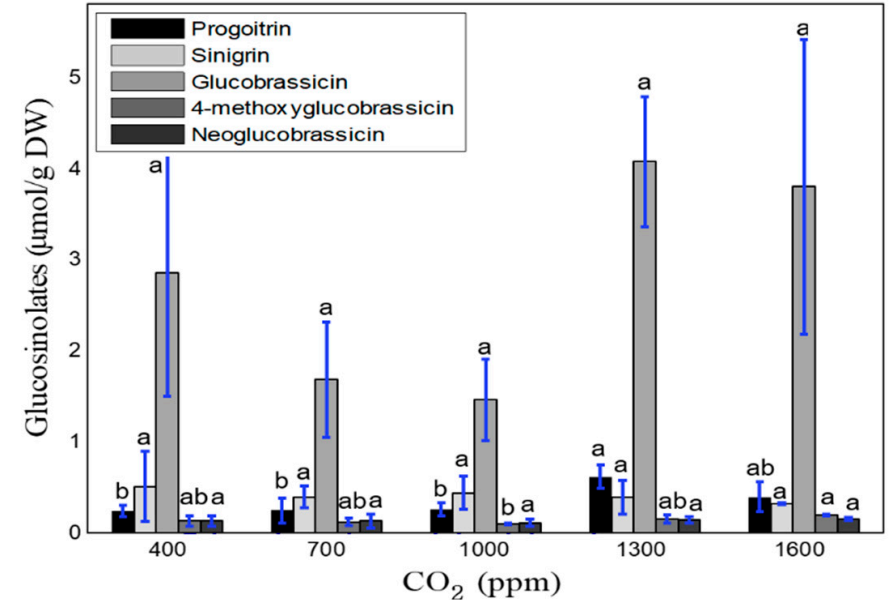

(b)

Figure 7. Concentrations of glucosinolate components $(\mu \mathrm{mol} / \mathrm{g} \mathrm{DW})$ under different $\mathrm{CO}_{2}$ treatments and cultivation periods: two weeks after transplantation (a) and four weeks after transplantation $(\mathbf{b}) .{ }^{a}$ b levels of components with the same letters are not significantly different at $p<0.05$.

Table 9 shows the interactions of each physical and functional parameter with one another, along with the significance levels for different $\mathrm{CO}_{2}$ treatments after four weeks of transplantation. Weak correlations (both positive and negative) were detected among most of the physical growth variables. However, the glucosinolate components (except sinigrin) were strongly positively correlated with each other and mostly negatively correlated with physical growth variables. According to the VIF analysis, the VIF values of the physical variables varied from 1 to 2 , except plant height (4.23), indicating low correlations. Contrariwise, the VIF values of the glucosinolate components (except progoitrin) were comparatively high, which indicated highly correlated relationships and influences on other predictors. 
Table 9. Correlation matrix showing kale growth and glucosinolate variables and their constituents (experiment 3).

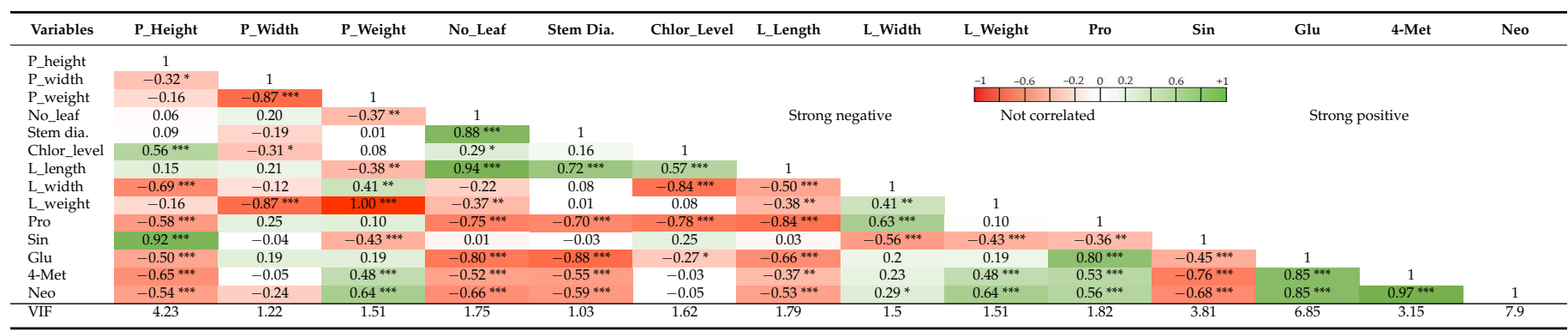

${ }^{*}, * *, * * *$ indicates the $5 \%, 1 \%$, and $0.1 \%$ significance level, respectively. P_height: plant height, P_width: plant width, P_weight: plant weight, No_leaf: number of leaves, Stem dia.: stem diameter, Chlor_level: chlorophyll level, L_length: leaf length, L_width: leaf width, L_weight: leaf weight, Pro: progoitrin, Sin: sinigrin, Glu: glucobrassicin, 4-Met: 4-methoxyglucobrassicin, and Neo: neoglucobrassicin. VIF: variance inflation factor.

\section{Discussion}

There is an interaction between plant growth and glucosinolate concentration, which strongly depends on the environmental conditions and water-nutrient consumption rate, along with the plant species, growth method, cultivation period, and cultivation facilities used $[12-14,16,49,50]$. In this study, the growth rate of kale increased with the cultivation period. The overall maximum growth rate was observed at $20-23{ }^{\circ} \mathrm{C}$, around $85 \%$ relative humidity, and 700-1000 ppm $\mathrm{CO}_{2}$ (Tables 4, 6 and 8). The optimal temperature, relative humidity, and $\mathrm{CO}_{2}$ range for total glucosinolate content were $14-17^{\circ} \mathrm{C}, 55-75 \%$, and $1300-1600 \mathrm{ppm}$. However, the glucosinolate content of kale decreased notably as cultivation period, temperature, and relative humidity level increased (Figures 5 and 6). Contrariwise, it increased with increased $\mathrm{CO}_{2}$ concentration (Figure 7). All biological processes of plants speed up at higher temperatures [51]. However, the sensitivity of plants to the atmospheric temperature depends on the growth stage. Plants always seek to maintain a balance between the plant-body temperature and air temperature. If the plant is heated up, the transpiration rate increases to cool down plants, which increases water and nutrient uptake, resulting in phonological changes in plants [52,53]. This assimilation process occurs quickly in the early growth stage. We observed a high growth rate at $23-26^{\circ} \mathrm{C}$ in the 2 nd week, which was reduced along with the temperature range (to $20-23^{\circ} \mathrm{C}$ ) in the 4 th week. However, the rapid transpiration process also ejects many nutrient components, which lowers the concentration of glucosinolate components, as shown in Figure 5 [33]. Conversely, a high level of accumulation of functional components (i.e., glucosinolates) occurs at low temperatures. Steindal et al. [29] explained that low temperatures activate cold acclimatization processes, including many biochemical and physiological changes, to improve the cold tolerance capacity. These procedures reduce the growth and accumulation of osmolytes and the functional component composition. In this study, the lowest rate of physical growth and the highest concentration of glucosinolates were also observed at $14{ }^{\circ} \mathrm{C}$ (Table 4, Figure 5). Velasco et al. [49] reported an inverse relationship between low temperatures and the total glucosinolate content. Relative humidity is directly related to $\mathrm{CO}_{2}$ acclimation through the stomata response, which is connected with plant growth and nutritional levels. Ahmed et al. [54] reviewed several studies and reported that a relative humidity of lower than $40 \%$ and higher than $85 \%$ causes stomatal malfunctioning, inhibiting the plant growth rate and photosynthesis. They also mentioned that the optimal range of relative humidity for leafy vegetables (i.e., lettuce) is $70-80 \%$. In this study, maximal growth was found at a relative humidity range of $75-85 \%$, and no significant difference was observed at a relative humidity range of $45-85 \%$ for the glucosinolate components (Figure 6), which matches the findings of previous studies. In addition to the effects of temperature and relative humidity, a significant impact of the $\mathrm{CO}_{2}$ concentration was observed on the accumulation of glucosinolate components rather than the growth rate of kale. In open environments, the concentration of $\mathrm{CO}_{2}$ remains constant (300-400 ppm), but this concentration can be increased in protected cultivation facilities (i.e., greenhouses and plant factories). Usually, the demand for $\mathrm{CO}_{2}$ increases with the increment of plant growth 
parameters and biomass [55]. In this study, $\mathrm{CO}_{2}$ concentrations of 700 to 1000 ppm were associated with better growth performance (Table 8), and higher glucosinolate formation was observed under 1300 to $1600 \mathrm{ppm}$ range of $\mathrm{CO}_{2}$ (Figure 7). Higher concentrations of $\mathrm{CO}_{2}$ help to synthesize larger amounts of carbohydrates and other functional components through photosynthesis $[13,38,40]$. Moreover, lower reduction of the photosynthetic ingredients under elevated $\mathrm{CO}_{2}$ concentrations improves the glucosinolate content $[39,41]$. An overaccumulation of glucosinolates was observed under experiment-1 (temperature) compared to experiments- 2 and 3 (relative humidity and $\mathrm{CO}_{2}$ ). We know glucosinolates are significantly affected by the variety, genetics, plant growth stage, irrigation level, growing media, and environmental variables (i.e., temperature, humidity, $\mathrm{CO}_{2}$, and light conditions). For example, Chen et al. [56] investigated the variation of glucosinolates in Chinese Brassica campestris vegetables (Chinese cabbage, purple cai-tai, choysum, pakchoi, and turnip) and reported that total glucosinolates varied from 14-130 mg/100 g fresh weight (FW), where He et al. [57] observed the minimum $(28.9 \mu \mathrm{mol} / 100 \mathrm{~g} \mathrm{FW})$ in broccoli and maximum $(278 \mu \mathrm{mol} / 100 \mathrm{~g} \mathrm{FW})$ in Chinese kale. From seedling to early flowering, the total glucosinolate content increased with plant age in B. oleracea leaves. After that point, the aliphatic glucosinolate content decreased dramatically over time as the glucosinolates transferred in the flower buds [49]. Qian et al. [58] investigated the effect of light quality on glucosinolate composition and content of Chinese kale sprouts under $23^{\circ} \mathrm{C}$ temperature, $80 \%$ relative humidity, $16 / 8 \mathrm{~h}$ photoperiod, and red: blue: white light condition, and observed 167.32-288.70 and 72.66-87.48 $\mu \mathrm{mol} / \mathrm{g}$ DW of total glucosinolates in shoots and roots, respectively. Similarly, temperature, humidity, and $\mathrm{CO}_{2}$ have an individual effect on glucosinolate components and accumulation. Rosa and Rodrigues [59] reported that the amount of glucosinolates increases $4-35 \%$ in the Brassica species in summer compared to winter seasons. They also observed $386 \pm 71 \mu \mathrm{mol} / 100 \mathrm{~g}$ DW of total glucosinolates in the Chinese cabbage leaves under $20^{\circ} \mathrm{C}$, which increased up to $409 \pm 104 \mu \mathrm{mol} / 100 \mathrm{~g} \mathrm{DW}$ under $30^{\circ} \mathrm{C}$. The possible reason behind this increment is the proportional relationship between temperature and the photosynthesis rate. However, glucosinolate components and contents are degraded under both very hot and cold temperatures. Although the light types, intensity, photoperiod, and EC-pH were kept constant in this study (for experiments 1,2 , and 3), the variation of glucosinolate levels was observed due to the individual effect of temperature, humidity, and $\mathrm{CO}_{2}$. As the experiment 1,2 , and 3 were conducted separately, the overaccumulation of glucosinolates under temperature treatments might have occurred due to the overall growing condition; however, it is very important to maintain consistency between experiments. To minimize the inconsistency between experiments, the following measurements could be considered to handle and minimize the variations. First, similar seedlings could be prepared as much as possible, so that pre-transplanting cannot affect the final harvested product. Moreover, the number of samples could be increased by cultivating kale in bigger and multiple plant beds. Finally, maintenance of the same cultivation condition through more accurate and precise control of the environmental variables is necessary.

In the correlation matrixes, strong positive correlations were observed among all the physical growth variables, except for the chlorophyll level. Negative correlations with other growth variables were shown. The most likely reason for this phenomenon is that chlorophyll is an indicator of the health of the photosynthetic apparatus, and the concentration (amount per mass) is a function of the leaf area. As the midrib and petiole of kale (depending on the cultivar) are large, the midrib might become enlarged, diluting the concentration of chlorophyll in the lamina during the growth period, which results in negative correlations with other growth variables [60]. Moreover, the efficiency of chlorophyll varies over time due to the engagement-disengagement of assorted photoprotective mechanisms under fluctuating light conditions. This results in energy loss (absorbed by chlorophyll as heat) and affects carbohydrate (glucose) accumulation. This might be another reason for the negative correlation with kale growth $[61,62]$. Besides this, glucosinolate components were strongly positively correlated with each other under elevated $\mathrm{CO}_{2}$ concentrations, because 
glucosinolate synthesis is proportionally related to photosynthesis [38]. The mechanisms of biochemical reactions are, in fact, very complex, and in many processes, the biochemical pathways are only hypothetical or assumed, and the intermediate reactions and products are not fully known. At any stage in the biochemical chain, double bonds, which are very reactive, may be affected by temperature, relative humidity, and $\mathrm{CO}_{2}$ as well as by free radicals in the environment. Particularly, glucosinolate synthesis can be illustrated according to the following steps: (1) radical substitution and the addition of water occurs at elevated temperatures and/or in the presence of radicals; (2) addition reactions to carbonnitrogen double bonds, resulting in carbonic acid esters; (3) electrophilic addition of water to double bonds that creates two new sigma bonds, resulting in the formation of alcohol; and (4) the occurrence of rearrangement, transposition, and isomerization involving double bonds, allyl radicals, and the glucose cycle. The increased reactivity of double bonds makes them very susceptible to environmental factors, specifically temperature, relative humidity, and $\mathrm{CO}_{2}$.

Cartea and Velasco [6] reported that the concentrations of glucosinolate components vary depending on genetics and environmental factors, along with the crop cultivation methods, harvest, storage, and even the processes of meal preparation. Velasco et al. [49] specifically showed that the concentrations of aliphatic glucosinolate components gradually increase in vegetative tissues (i.e., leaves) and are transferred to the reproductive tissues (i.e., flowers and seeds) during the flowering period. In addition, the indole glucosinolate components of leaves and flower buds gradually decrease after a certain period of cultivation. However, the concentrations of aromatic glucosinolates do not vary significantly with the cultivation period. In this study, kale was cultivated in the plant factory using an aeroponic method (one type of hydroponics). The fast growth rate due to proper ambient environment and nutrient management might be a reason for high glucosinolate accumulation in the early stage (two weeks after transplantation), and it gradually declined with the cultivation period (four weeks after transplantation). Determination of the proper harvesting time of brassicaceous plants has been investigated in several studies [63,64]. Based on the environmental factors and cultivation methods used in this study, early harvesting (2-3 weeks after transplantation) is suggested as a possible strategy to achieve glucosinolate-rich kale.

\section{Conclusions}

This study was conducted to investigate the effects of temperature, relative humidity, and $\mathrm{CO}_{2}$ on the growth and glucosinolate content of kale plants hydroponically grown in a plant factory, where five different treatments of each environmental variable were applied separately, and samples were collected after two different periods of cultivation. According to the results, the optimal temperature, relative humidity, and $\mathrm{CO}_{2}$ range for growth and total glucosinolate content were $20-23{ }^{\circ} \mathrm{C}, 85 \%$, and $700-1000 \mathrm{ppm}$, and $14-17^{\circ} \mathrm{C}, 55-75 \%$, and 1300-1600 ppm, respectively. The glucosinolate content of kale was high in the early growth stage, with low temperature and humidity levels, and elevated $\mathrm{CO}_{2}$ concentrations. Strong positive correlations were observed among the physical growth variables, and weak correlations were found between the growth and glucosinolate parameters, which indicated that high physical growth might not ensure the high concentration of glucosinolates. According to the findings of this study, early harvesting (i.e., after 2 weeks of transplantation) could be preferred. As the optimum level of temperature, humidity, and $\mathrm{CO}_{2}$ was different in two- and four-week sampling times, dynamic ambient environment management might be adopted. Farmers could maintain the optimum range of each environmental variable separately based on their target (growth or glucosinolate level), or preferred combined management of the temperature, relative humidity, and $\mathrm{CO}_{2}$ during kale cultivation within protected cultivation facilities.

Author Contributions: Conceptualization, S.-O.C. and M.C.; methodology, S.-O.C. and M.C.; software, M.C.; validation, M.C.; formal analysis, M.C., S.K., M.N.I., M.A., M.N.R., W.-H.L. and S.-O.C.; investigation, S.-O.C. and W.-H.L.; resources, S.-O.C.; data curation, M.C., S.K., M.N.I., M.N.R. and 
M.A.; writing-original draft preparation, M.C.; writing-review and editing, S.-O.C. and W.-H.L.; visualization, M.C., S.K., M.N.I., M.A. and M.N.R.; supervision, S.-O.C.; project administration, S.-O.C.; funding acquisition, S.-O.C. All authors have read and agreed to the published version of the manuscript.

Funding: This work was supported by the Korea Institute of Planning and Evaluation for Technology in Food, Agriculture and Forestry (IPET) through the Agriculture, Food and Rural Affairs Convergence Technologies Program for Educating Creative Global Leaders, funded by Ministry of Agriculture, Food and Rural Affairs (MAFRA) (project No. 320001-4), Republic of Korea.

Institutional Review Board Statement: Not applicable.

Informed Consent Statement: Not applicable.

Data Availability Statement: All the data reported here are available from the authors upon request.

Conflicts of Interest: The authors declare no conflict of interest.

\section{References}

1. Chang, J.; Wang, M.; Jian, Y.; Zhang, F.; Zhu, J.; Wang, Q.; Sun, B. Health-promoting phytochemicals and antioxidant capacity in different organs from six varieties of Chinese kale. Sci. Rep. 2019, 9, 20344. [CrossRef]

2. Abellán, Á.; Domínguez-Perles, R.; Moreno, D.A.; García-Viguera, C. Sorting out the value of cruciferous sprouts as sources of bioactive compounds for nutrition and health. Nutrients 2019, 11, 429. [CrossRef]

3. Jeon, J.; Kim, J.K.; Kim, H.; Kim, Y.J.; Park, Y.J.; Kim, S.J.; Kim, C.; Park, S.U. Transcriptome analysis and metabolic profiling of green and red kale (Brassica oleracea var. Acephala) seedlings. Food Chem. 2018, 241, 7-13. [CrossRef]

4. Giorgetti, L.; Giorgi, G.; Cherubini, E.; Gervasi, P.G.; Croce, C.M.D.; Longo, V.; Bellani, L. Screening and identification of major phytochemical compounds in seeds, sprouts and leaves of tuscan black kale Brassica oleracea (L.) ssp Acephala (DC) Var. Sabellica L. Nat. Prod. Res. 2018, 32, 1617-1626. [CrossRef]

5. Akram, W.; Saeed, T.; Ahmad, A.; Yasin, N.A.; Akbar, M.; Khan, W.U.; Ahmed, S.; Guo, J.; Luo, W.; Wu, T.; et al. Liquiritin elicitation can increase the content of medicinally important glucosinolates and phenolic compounds in chinese kale plants. J. Sci. Food Agric. 2020, 100, 1616-1624. [CrossRef] [PubMed]

6. Cartea, M.E.; Velasco, P. Glucosinolates in Brassica Foods: Bioavailability in Food and Significance for Human Health. Phytochem. Rev. 2008, 7, 213-229. [CrossRef]

7. Agerbirk, N.; Olsen, C.E. Glucosinolate Structures in Evolution. Phytochemistry 2012, 77, 16-45. [CrossRef]

8. Holst, B.; Fenwick, G.R. Glucosinolates. In Encyclopedia of Food Sciences and Nutrition, 2nd ed.; Caballero, B., Ed.; Academic Press: Oxford, UK, 2003; pp. 2922-2930. ISBN 978-0-12-227055-0.

9. Mithen, R.F.; Dekker, M.; Verkerk, R.; Rabot, S.; Johnson, I.T. The nutritional significance, biosynthesis and bioavailability of glucosinolates in human foods. J. Sci. Food Agric. 2000, 80, 967-984. [CrossRef]

10. Johnson, I.T. Glucosinolates: Bioavailability and importance to health. Int. J. Vitam. Nutr. Res. 2002, 72, 26-31. [CrossRef] [PubMed]

11. Piotrowski, M.; Schemenewitz, A.; Lopukhina, A.; Müller, A.; Janowitz, T.; Weiler, E.W.; Oecking, C. Desulfoglucosinolate sulfotransferases from arabidopsis thaliana catalyze the final step in the biosynthesis of the glucosinolate core structure. J. Biol. Chem. 2004, 279, 50717-50725. [CrossRef]

12. Neugart, S.; Baldermann, S.; Hanschen, F.S.; Klopsch, R.; Wiesner-Reinhold, M.; Schreiner, M. The intrinsic quality of brassicaceous vegetables: How secondary plant metabolites are affected by genetic, environmental, and agronomic factors. Sci. Hortic. 2018, 233, 460-478. [CrossRef]

13. Singh, S.K.; Reddy, V.R.; Sharma, M.P.; Agnihotri, R. Dynamics of plant nutrients, utilization and uptake, and soil microbial community in crops under ambient and elevated carbon dioxide. In Nutrient Use Efficiency: From Basics to Advances; Rakshit, A., Singh, H.B., Sen, A., Eds.; Springer India: New Delhi, India, 2015; pp. 381-399. ISBN 978-81-322-2169-2.

14. Lee, G.J.; Heo, J.W.; Jung, C.R.; Kim, H.H.; Jo, J.S.; Lee, J.G.; Lee, G.J.; Nam, S.Y.; Hong, E.Y. Effects of artificial light sources on growth and glucosinolate contents of hydroponically grown kale in plant factory. Prot. Hort. Plant Fac. 2016, 25, 77-82. [CrossRef]

15. Lee, H.H.; Yang, S.C.; Lee, M.K.; Ryu, D.K.; Park, S.; Chung, S.O.; Park, S.U.; Lim, Y.P.; Kim, S.J. Effect of developmental stages on glucosinolate contents in kale (Brassica oleracea var. acephala). Hortic. Sci. Technol. 2015, 33, 177-185. [CrossRef]

16. Kim, K.H.; Chung, S.O. Comparison of plant growth and Glucosinolates of Chinese cabbage and Kale crops under three cultivation conditions. J. Biosyst. Eng. 2018, 43, 30-36. [CrossRef]

17. Kozai, T. Smart Plant Factory: The Next Generation Indoor Vertical Farms; Springer: Singapore, 2018; ISBN 9789811310652.

18. Chowdhury, M.; Kabir, M.S.N.; Kim, H.T.; Chung, S.O. Method of pump, pipe, and tank selection for aeroponic nutrient management systems based on crop requirements. J. Agric. Eng. 2020, 51, 119-128. [CrossRef]

19. Kozai, T.; Niu, G.; Takagaki, M. Plant Factory: An Indoor Vertical Farming System for Efficient Quality Food Production; Academic Press: London, UK, 2019; ISBN 978-0-12-816692-5. 
20. Chowdhury, M.; Jang, B.E.; Kabir, M.S.N.; Lee, D.H.; Kim, H.T.; Park, T.S.; Chung, S.O. Performance Evaluation of Commercial Ion-Selective Electrodes for Hydroponic Cultivation System. Acta Hortic. 2020, 831-838. [CrossRef]

21. Jung, D.H.; Kim, H.J.; Choi, G.L.; Ahn, T.I.; Son, J.E.; Sudduth, K.A. Automated lettuce nutrient solution management using an array of ion-selective electrodes. Trans. ASABE 2015, 58, 1309-1319.

22. Chowdhury, M.; Jang, B.E.; Kabir, M.S.N.; Kim, Y.J.; Na, K.D.; Park, S.B.; Chung, S.O. Factors affecting the accuracy and precision of ion-selective electrodes for hydroponic nutrient supply systems. Acta Hortic. 2020, 997-1004. [CrossRef]

23. Cho, W.J.; Kim, H.J.; Jung, D.H.; Kim, D.W.; Ahn, T.I.; Son, J.E. On-site ion monitoring system for precision hydroponic nutrient management. Comput. Electron. Agric. 2018, 146, 51-58. [CrossRef]

24. Benton Jones, J. Hydroponics: A Practical Guide for the Soilless Grower; CRC Press: Boca Raton, FL, USA, 2016; ISBN 978-1-4200-3770-8.

25. Li, Q.; Li, X.; Tang, B.; Gu, M. Growth responses and root characteristics of lettuce grown in aeroponics, hydroponics, and substrate culture. Horticulturae 2018, 4, 35. [CrossRef]

26. Wu, X.; Huang, H.; Childs, H.; Wu, Y.; Yu, L.; Pehrsson, P.R. Glucosinolates in Brassica vegetables: Characterization and factors that influence distribution, content, and intake. Annu. Rev. Food Sci. Technol. 2021, 12, 43-73. [CrossRef]

27. Alegre, S.; Pascual, J.; Trotta, A.; Gollan, P.J.; Yang, W.; Yang, B.; Aro, E.-M.; Burow, M.; Kangasjärvi, S. Growth under high light and elevated temperature affects metabolic responses and accumulation of health-promoting metabolites in kale varieties. bioRxiv 2019, 816405. [CrossRef]

28. McClung, C.R.; Lou, P.; Hermand, V.; Kim, J.A. The Importance of ambient temperature to growth and the induction of flowering. Front. Plant Sci. 2016, 7. [CrossRef]

29. Steindal, A.L.H.; Rødven, R.; Hansen, E.; Mølmann, J. Effects of photoperiod, growth temperature and cold acclimatisation on glucosinolates, sugars and fatty acids in Kale. Food Chem. 2015, 174, 44-51. [CrossRef]

30. Lee, J.H.; Oh, M.M. Short-term low temperature increases phenolic antioxidant levels in kale. Hortic. Environ. Biotechnol. 2015, 56, 588-596. [CrossRef]

31. Maibam, A.; Nisar, S.; Zargar, S.M.; Mahajan, R. High-temperature response and tolerance in agronomic crops. In Agronomic Crops: Volume 3: Stress Responses and Tolerance; Hasanuzzaman, M., Ed.; Springer: Singapore, 2020; pp. 173-190. ISBN 9789811500251.

32. Soengas, P.; Rodríguez, V.M.; Velasco, P.; Cartea, M.E. Effect of temperature stress on antioxidant defenses in Brassica oleracea. Acs Omega 2018, 3, 5237-5243. [CrossRef]

33. Anjum, S.A.; Xie, X.; Wang, L.; Saleem, M.F.; Man, C.; Lei, W. Morphological, physiological and biochemical responses of plants to drought stress. Afr. J. Agric. Res. 2011, 6, 2026-2032. [CrossRef]

34. Han, W.; Yang, Z.; Huang, L.; Sun, C.; Yu, X.; Zhao, M. Fuzzy comprehensive evaluation of the effects of relative air humidity on the morpho-physiological traits of Pakchoi (Brassica Chinensis L.) under high temperature. Sci. Hortic. 2019, 246, 971-978. [CrossRef]

35. Avotins, A.; Gruduls, J.; Apse-Apsitis, P.; Bicāns, J. Development and testing results of iot based air temperature and humidity measurement system for industrial greenhouse. Agron. Res. 2018, 16, 943-951.

36. Amani, M.; Foroushani, S.; Sultan, M.; Bahrami, M. Comprehensive review on dehumidification strategies for agricultural greenhouse applications. Appl. Therm. Eng. 2020, 181, 115979. [CrossRef]

37. Islam, M.N.; Iqbal, M.Z.; Ali, M.; Jang, B.E.; Chowdhury, M.; Kabir, M.S.N.; Jang, S.H.; Chung, S.O. Performance evaluation of a suspension-type dehumidifier with a heating module for smart greenhouses. J. Biosyst. Eng. 2020, 45, 155-166. [CrossRef]

38. La, G.; Fang, P.; Teng, Y.; Li, Y.; Lin, X. Effect of $\mathrm{CO}_{2}$ enrichment on the Glucosinolate contents under different nitrogen levels in bolting stem of Chinese Kale (Brassica Alboglabra L.). J. Zhejiang Univ. Sci. B 2009, 10, 454-464. [CrossRef] [PubMed]

39. Ainsworth, E.A.; Long, S.P. What have we learned from 15 years of free-air $\mathrm{CO}_{2}$ enrichment (FACE)? A Meta-Analytic Review of the Responses of Photosynthesis, Canopy Properties and Plant Production to Rising $\mathrm{CO}_{2}$. New Phytol. 2005, 165, 351-372. [CrossRef] [PubMed]

40. Madhu, M.; Hatfield, J.L. Dynamics of plant root growth under increased atmospheric Carbon Dioxide. Agron. J. 2013, 105, 657-669. [CrossRef]

41. Kimball, B.A. Crop responses to elevated $\mathrm{CO}_{2}$ and interactions with $\mathrm{H}_{2} \mathrm{O}, \mathrm{N}$, and temperature. Curr. Opin. Plant Biol. 2016, 31, 36-43. [CrossRef]

42. Chung, S.O.; Kang, S.W.; Bae, K.S.; Ryu, M.J.; Kim, Y.J. The potential of remote monitoring and control of protected crop production environment using mobile phone under $3 \mathrm{G}$ and Wi-Fi communication conditions. Eng. Agric. Environ. Food 2015, 8, 251-256. [CrossRef]

43. Zhang, Y.; Ji, J.; Song, S.; Su, W.; Liu, H. Growth, nutritional quality and health-promoting compounds in Chinese Kale grown under different ratios of red:blue LED lights. Agronomy 2020, 10, 1248. [CrossRef]

44. Lefsrud, M.G.; Kopsell, D.A.; Sams, C.E. Irradiance from distinct wavelength light-emitting diodes affect secondary metabolites in Kale. HortScience 2008, 43, 2243-2244. [CrossRef]

45. Naznin, M.T.; Lefsrud, M.; Gravel, V.; Azad, M.O.K. Blue light added with red leds enhance growth characteristics, pigments content, and antioxidant capacity in lettuce, spinach, kale, basil, and sweet pepper in a controlled environment. Plants $2019,8,93$. [CrossRef]

46. Doheny-Adams, T.; Redeker, K.; Kittipol, V.; Bancroft, I.; Hartley, S.E. Development of an efficient glucosinolate extraction method. Plant Methods 2017, 13, 17. [CrossRef] 
47. ISO 9167:2019 Rapeseed and Rapeseed Meals—Determination of Glucosinolates Content—Method Using High-Performance Liquid Chromatography. Available online: https:/ / www.iso.org/standard/72207.html (accessed on 15 June 2021).

48. Hair, J.F., Jr.; Black, W.C.; Babin, B.J.; Anderson, R.E. Multivariate Data Analysis: A Global Perspective, 7th ed.; Prentice Hall: Upper Saddle River, NJ, USA, 2009.

49. Velasco, P.; Cartea, M.E.; González, C.; Vilar, M.; Ordás, A. Factors affecting the glucosinolate content of kale (Brassica oleracea Acephala Group). J. Agric. Food Chem. 2007, 55, 955-962. [CrossRef]

50. Bohinc, T.; Trdan, S. Environmental factors affecting the glucosinolate content in brassicaceae. J. Food Agric. Environ. 2012, 10, 357-360.

51. Hatfield, J.L.; Prueger, J.H. Temperature extremes: Effect on plant growth and development. Weather Clim. Extrem. 2015, 10, 4-10. [CrossRef]

52. Keenan, T.F.; Richardson, A.D.; Hufkens, K. On Quantifying the apparent temperature sensitivity of plant phenology. New Phytol. 2020, 225, 1033-1040. [CrossRef] [PubMed]

53. Lapenis, A.; Henry, H.; Vuille, M.; Mower, J. Climatic factors controlling plant sensitivity to warming. Clim. Chang. 2014, 122, 723-734. [CrossRef]

54. Ahmed, H.A.; Yu-Xin, T.; Qi-Chang, Y. Optimal Control of Environmental Conditions Affecting Lettuce Plant Growth in a Controlled Environment with Artificial Lighting: A Review. S. Afr. J. Bot. 2020, 130, 75-89. [CrossRef]

55. Kaiser, E.; Morales, A.; Harbinson, J.; Kromdijk, J.; Heuvelink, E.; Marcelis, L.F.M. Dynamic photosynthesis in different environmental conditions. J. Exp. Bot. 2015, 66, 2415-2426. [CrossRef] [PubMed]

56. Chen, X.; Zhu, Z.; Gerendás, J.; Zimmermann, N. Glucosinolates in Chinese Brassica Campestris Vegetables: Chinese Cabbage, Purple Cai-Tai, Choysum, Pakchoi, and Turnip. HortScience 2008, 43, 571-574. [CrossRef]

57. He, H.; Liu, L.; Song, S.; Tang, X.; Wang, Y. Evaluation of glucosinolate composition and contents in chinese brassica vegetables. Acta Hortic. 2003, 85-92. [CrossRef]

58. Qian, H.; Liu, T.; Deng, M.; Miao, H.; Cai, C.; Shen, W.; Wang, Q. Effects of Light Quality on Main Health-Promoting Compounds and Antioxidant Capacity of Chinese Kale Sprouts. Food Chem. 2016, 196, 1232-1238. [CrossRef]

59. Rosa, E.A.S.; Rodrigues, P.M.F. The Effect of Light and Temperature on Glucosinolate Concentration in the Leaves and Roots of Cabbage Seedlings. J. Sci. Food Agric. 1998, 78, 208-212. [CrossRef]

60. Lin, K.H.; Shih, F.C.; Huang, M.Y.; Weng, J.H. Physiological characteristics of photosynthesis in yellow-green, green and dark-green Chinese kale (Brassica oleracea L. var. Alboglabra Musil.) under varying light intensities. Plants 2020, 9, 960. [CrossRef]

61. Blankenship, R.E. Molecular Mechanisms of Photosynthesis; John Wiley \& Sons: St. Louis, MO, USA, 2014; ISBN 978-1-4051-8976-7.

62. Eberhard, S.; Finazzi, G.; Wollman, F.A. The dynamics of photosynthesis. Annu. Rev. Genet. 2008, 42, 463-515. [CrossRef]

63. Hagen, S.F.; Borge, G.I.A.; Solhaug, K.A.; Bengtsson, G.B. Effect of cold storage and harvest date on bioactive compounds in curly kale (Brassica oleracea L. var. Acephala). Postharvest Biol. Technol. 2009, 51, 36-42. [CrossRef]

64. Yoon, H.I.; Kim, J.S.; Kim, D.; Kim, C.Y.; Son, J.E. Harvest strategies to maximize the annual production of bioactive compounds, glucosinolates, and total antioxidant activities of kale in plant factories. Hortic. Environ. Biotechnol. 2019, 60, 883-894. [CrossRef] 